\title{
Cellular Physiology

\section{Ion Channels Involved in Cell Volume Regulation: Effects on Migration, Proliferation, and Pro- grammed Cell Death in Non Adherent EAT Cells and Adherent ELA Cells}

\section{Else Kay Hoffmann*}

\begin{abstract}
Section of Cell and Developmental Biology, Department of Biology, University of Copenhagen,
\end{abstract} Copenhagen

*recipient of the "Yasu Okada Medal"

\section{Key Words}

VRAC - TMEM16 - TASK-2 - RVD • Osmotic stress • Cell migration - Cell proliferation - Programmed cell death $\cdot$ Apoptosis

\begin{abstract}
This mini review outlines studies of cell volume regulation in two closely related mammalian cell lines: nonadherent Ehrlich ascites tumour cells (EATC) and adherent Ehrlich Lettre ascites (ELA) cells. Focus is on the regulatory volume decrease (RVD) that occurs after cell swelling, the volume regulatory ion channels involved, and the mechanisms (cellular signalling pathways) that regulate these channels. Finally, I shall also briefly review current investigations in these two cell lines that focuses on how changes in cell volume can regulate cell functions such as cell migration, proliferation, and programmed cell death.
\end{abstract}

Copyright @ 2011 S. Karger AG, Basel

\section{KARGER}

Fax +41613061234 E-Mail karger@karger.ch www.karger.com
(C) 2011 S. Karger AG, Basel 1015-8987/11/0286-1061\$38.00/0

Accessible online at: www.karger.com/cpb

\section{Introduction}

Current knowledge of cell volume homeostasis supports the notion of a pump-leak balance, based on the pump-leak, steady-state concept introduced by Krogh [1] and analysed in detail by Leaf [2], Ussing [3], and Tosteson and Hoffman [4]. Later, many of the classical "leak" pathways were found to be the actual effectors of volume regulation, due to their extreme sensitivity to changes in cell volume. This mini review will discuss two of these effector pathways (the $\mathrm{K}^{+}$and $\mathrm{Cl}^{-}$channels involved in RVD) and their regulation in two model cell types: Ehrlich ascites tumour cells (EATC) and Ehrlich Lettre ascites (ELA) cells. The basic physiology of cell volume regulation has been detailed in previous reviews [5-7].

\section{Regulatory volume decrease (RVD)}

In EATCs, the osmotic permeability to water is $10^{5}$ times higher than the permeabilities to $\mathrm{K}^{+}$and $\mathrm{Na}^{+}$[8] and $10^{6}$ times higher than the permeability to $\mathrm{Cl}^{-}[9]$. Thus,

Else K Hoffmann, Ph.D.

Dept. of Biology, University of Copenhagen, 13, Universitetsparken DK-2100 Copenhagen (Denmark)

Tel. +45 35321695, Fax +45 35321567

E-Mailekhoffmann@bio.ku.dk 
a decrease in the extracellular osmolarity or an increase in the intracellular osmolarity leads to a rapid increase in cell volume. The cell swells like an almost perfect osmometer, followed by a regulatory volume decrease (RVD) (Fig. 1). The steady-state cell volume attained after the RVD process is typically greater than the initial cell volume and depends on the degree of initial cell swelling. Thus, after RVD, at a relative extracellular tonicity of 0.5 (Fig. 1), EATC cell volume stabilizes at $1.23 \pm 0.01$ $(n=23)$ times the initial cell volume [10]; however, at relative tonicity of 0.75 , EATC cell volume stabilizes to $1.09 \pm 0.01(\mathrm{n}=6)$ [10]. The mechanism for this increase in the new steady -state volume obtained after swelling and RVD is not well understood. The volume obtained after the RVD process may increase with decreasing intracellular ionic strength, or it may increase with the decrease in $\left[\mathrm{Cl}^{-}\right]_{\mathrm{i}}[7]$. Several signalling molecules can affect this volume. Thus, we have found that in EATCs it increased after inhibition of Ser/Thr phosphatases and decreased after inhibition of tyrosine phosphatases (see $[7,10-12]$. It is important to mention that cells do not have one preferred cell volume; thus, the cell volume depends on the functional state of the cell; furthermore, altered cell volume can be a physiological signal, as in cell cycle progression and programmed cell death (see below). Actually, cell volume appears to play essential signalling roles in a wide range of physiological and pathophysiological processes; I shall discuss a few of these at the end of the review.

\section{Effectors of RVD in EATC and ELA cells}

Below, I shall discuss findings that have led to our current understanding of the structural basis and function of ion channels involved in volume regulation in EATC and ELA cells. In addition, In shall discuss the biochemical basis for channel regulation. Focus will be on the two main types of channels involved in RVD: swelling -activated $\mathrm{Cl}^{-}$and $\mathrm{K}^{+}$channels.

\section{Swelling-activated $\mathrm{Cl}^{-}$channels}

It was first demonstrated in EATCs that cell swelling induced the activation of a $\mathrm{Cl}^{-}$leak pathway [8]. This was also shown in lymphocytes [13] and later, in essentially all cell types investigated [14, 15]. Direct electrophysiological recordings of swelling -activated $\mathrm{K}^{+}$ and $\mathrm{Cl}^{-}$currents were first carried out in human intestine 407 cells [16]; later, the activation of separate $\mathrm{K}^{+}$and $\mathrm{Cl}^{-}$ channels was measured during RVD in many cells $[5,7]$.

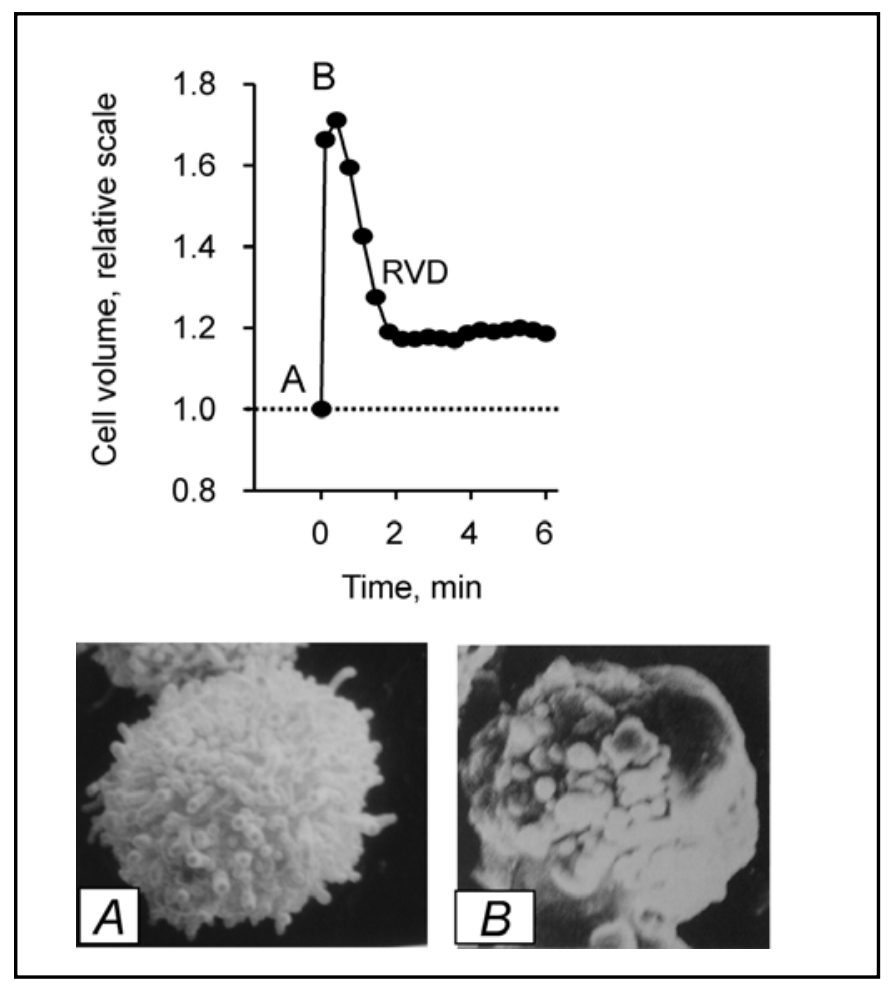

Fig. 1. Regulatory volume decrease (RVD) in EATCs. Cells were preincubated in isotonic (300 mOsm) medium for $40 \mathrm{~min}$. At time $=0(\mathrm{~A})$, they were transferred to hypotonic medium $(150$ mOsm). (Top panel) Cell volume was followed over time with a Coulter counter. The maximal swelling (B) was followed by cell shrinking (RVD). Cell volume is expressed relative to the initial isotonic volume. (Bottom panel) Images were taken by scanning electron microscopy at time points indicated in the top panel (A, B). Images are from [8]. The figure is reproduced from [7] with permission from The American Physiological Society.

It was originally assumed that, in the basal steady state, the $\mathrm{Cl}^{-}$conductance $\left(\mathrm{g}_{\mathrm{C}}\right)$ was high, and an increase in $\mathrm{g}_{\mathrm{Cl}}$ was not necessary for RVD to take place. However, around 1970 [17], a Cl- exchange diffusion was demonstrated, and it became clear that the net conductive $\mathrm{Cl}^{-}$ transport could be much smaller than assumed from unidirectional flux measurements, because the major part of the flux was due to $\mathrm{Cl}^{-} / \mathrm{Cl}^{-}$exchange. Thus, in 1979, we found in EATCs that the conductive $\mathrm{Cl}^{-}$permeability accounts for only $5 \%$ of the apparent permeability deduced from unidirectional ${ }^{36} \mathrm{Cl}^{-}$efflux measurements. [18]. Furthermore, ${ }^{36} \mathrm{Cl}^{-}$efflux increased in swollen cells and it was inferred that this increase reflects a dramatic increase in $\mathrm{Cl}^{-}$conductance upon swelling [8] (Fig. 2A), which occurred in parallel with an increase in conductive $\mathrm{K}^{+}$flux [19]. This resulted in a net $\mathrm{KCl}$ efflux and led to RVD. To understand the $\mathrm{Cl}^{-}$loss during $\mathrm{RVD}$ it is important to know that in EATC, $\left[\mathrm{Cl}^{-}\right]_{\mathrm{i}}$ is much higher than predicted from thermodynamic equilibrium [9]. The increase in ${ }^{36} \mathrm{Cl}$ 
Fig. 2. Volume-regulated $\mathrm{Cl}^{-}$permeability. (A) The rate constant for ${ }^{36} \mathrm{Cl}$ efflux was dependent on cell volume in EATC. Efflux was measured as a unidirectional, steady state ${ }^{36} \mathrm{Cl}$ efflux. The $\mathrm{NaCl}$ concentration is in all cases $75 \mathrm{mM}$, and differences in osmolarity are obtained by addition of different amounts of sucrose. Under isotonic conditions, (dashed line) the electroneutral anion exchanger (AE) was responsible for $95 \%$ of the efflux, and the remaining $5 \%$ constituted a conductive $\mathrm{Cl}^{-}$flux (volume-regulated anion current; VRAC). Increase in $\mathrm{Cl}^{-}$flux on cell swelling was taken to represent an activation of conductive $\mathrm{Cl}^{-}$channels. Thus VRAC increased significantly after cell swelling (cell water $>4 \mathrm{mg} / \mathrm{g}$ dry wt). The anion/cation cotransporter (NKCC), which was quiescent under isotonic conditions, was responsible for the increased unidirectional $\mathrm{Cl}^{-}$flux in shrunken cells (cell water $<3.5 \mathrm{mg} / \mathrm{g}$ dry wt). [Data from [8]]. (B) Changes in EATC volume after transfer (at time=0) to a hypotonic (150 mOsm), $\mathrm{Na}^{+}$-free medium that contained a $\mathrm{K}^{+}$channel inhibitor (quinine). Gramicidin $(0.5 \mu \mathrm{M})$ was added to induce high $\mathrm{K}^{+}$permeability. When the $\mathrm{K}^{+}$channel is blocked by quinine but bypassed by addition of gramicidin, the rate of cell shrinkage can be used to monitor the $\mathrm{Cl}^{-}$conductance. The $\mathrm{Cl}^{-}$conductance is increased about 60 -fold when the cells are swollen and decreases again within 10 minutes following the hypotonic exposure. The volume-induced activation of the $\mathrm{Cl}^{-}$ transport pathway is transient, with inactivation within about 10 minutes[Data from [20]]. (C) I-V relationship obtained with whole cell patch clamp recordings $(-100 \mathrm{mV}$ to $+100 \mathrm{mV}$, using a fast ramp-protocol) of the $\mathrm{Cl}^{-}$current (VRAC) in EATCs under isotonic and hypotonic ( $27 \%$ decrease in osmolarity) conditions. [Data from [23]]. The figure is reproduced from [7] with permission from the American Physiological Society.

exchange flux seen in shrunken cells reflects an activation of anion cation cotransport, later shown to be $\mathrm{Na}^{+}$, $\mathrm{K}^{+} 2 \mathrm{Cl}^{-}$cotransport (see [7]). In the experiments [20] shown in Fig. 2B, we recorded the RVD process, when the $\mathrm{K}^{+}$channel was blocked by quinine but bypassed by addition of the $\mathrm{K}^{+}$ionophore gramicidin. Under these conditions the rate of cell shrinkage could be used to monitor the $\mathrm{Cl}^{-}$conductance, which was now rate limiting for the cell shrinkage. This experiment demonstrated that $\mathrm{Cl}^{-}$permeability increased within the first minute after cell swelling and decreased again after about $10 \mathrm{~min}$. In isotonic steady state, the EATC membrane conductances were estimated to be $10.4 \mu \mathrm{S} / \mathrm{cm}^{2}$ for $\mathrm{K}^{+}$and 0.6 $\mu \mathrm{S} / \mathrm{cm}^{2}$ for $\mathrm{Cl}^{-}$[9]. Upon cell swelling, it was shown that the $\mathrm{Cl}^{-}$conductance increased around 60 -fold, which was significantly greater than the change in $\mathrm{K}^{+}$conductance [9]. In EATC, $\left[\mathrm{Cl}^{-}\right]_{\mathrm{i}}$ is much higher than predicted from thermodynamic equilibrium; therefore, this large increase in $\mathrm{Cl}^{-}$conductance results in a depolarization of the cell membrane during RVD [9]. Cellular $\mathrm{Cl}^{-}$homeostasis in EATC was previously described in [21]. A more general

Ion Channels in Regulatory Volume Decrease in Ehrlich Cells

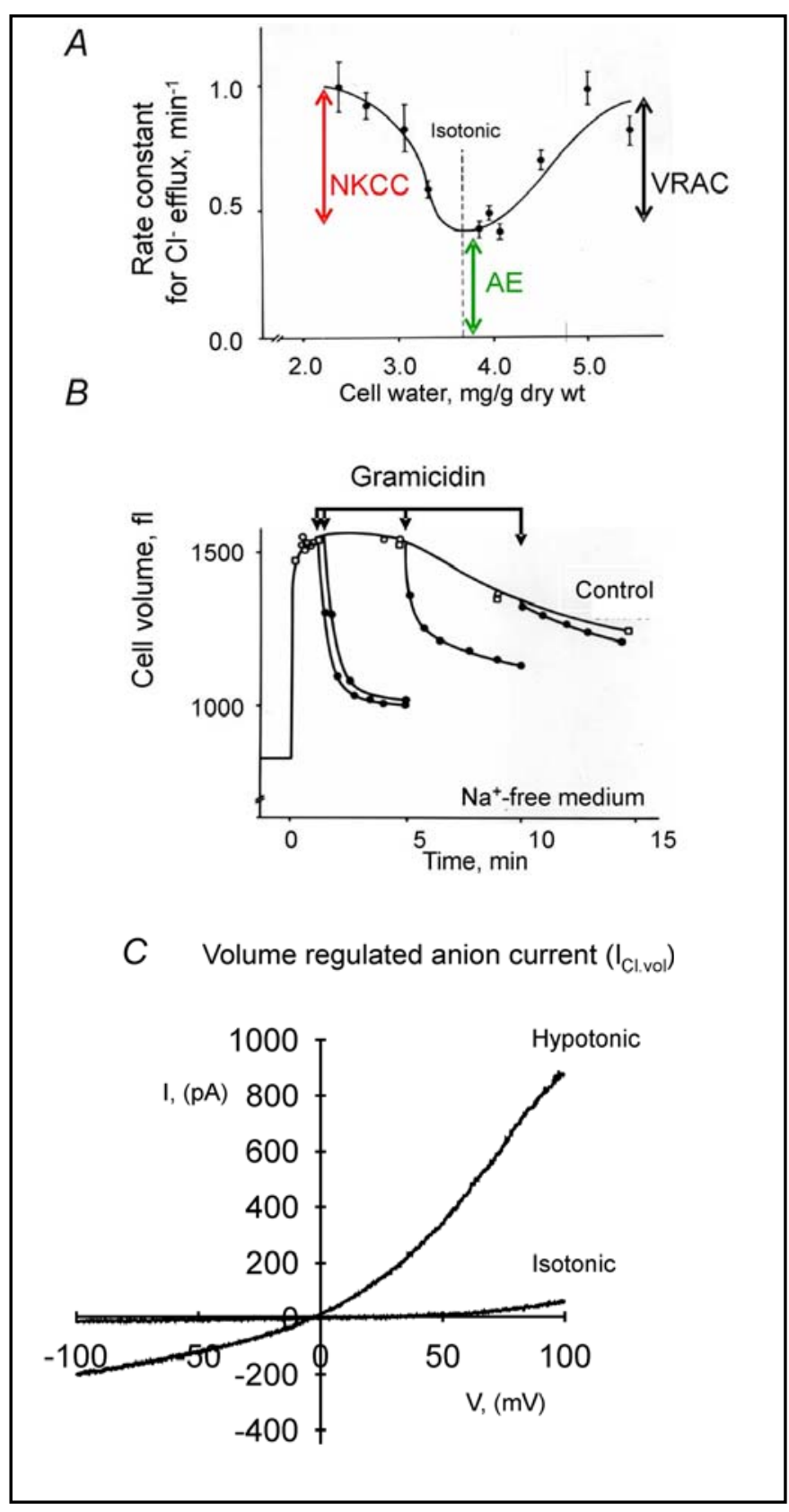

description of cellular $\mathrm{Cl}^{-}$homeostasis is found in [22]

\section{Characteristics of swelling-activated Cl- currents}

The biophysical characteristics of swelling -activated $\mathrm{Cl}^{-}$channels (a.k.a. the volume regulated anion current, VRAC) in EATC [23] and in ELA cells [24] were similar to those found in other cells. These characteristics included moderate outward rectification (Fig. 2C), timeand depolarization-induced inactivation, and an Eisenman I permeability sequence of $\mathrm{SNC}^{-}>\mathrm{I}^{-}>\mathrm{NO}^{-}>\mathrm{Br}^{-}>\mathrm{Cl}^{-}$ $>\mathrm{F}^{-}[7,15,25]$. Depolarization-induced inactivation was not very strong in EATC [23] compared to the massive response in rat C6 glioma cells [26] and the more or less lack of inactivation in Jurkat lymphocytes [27] and mouse 


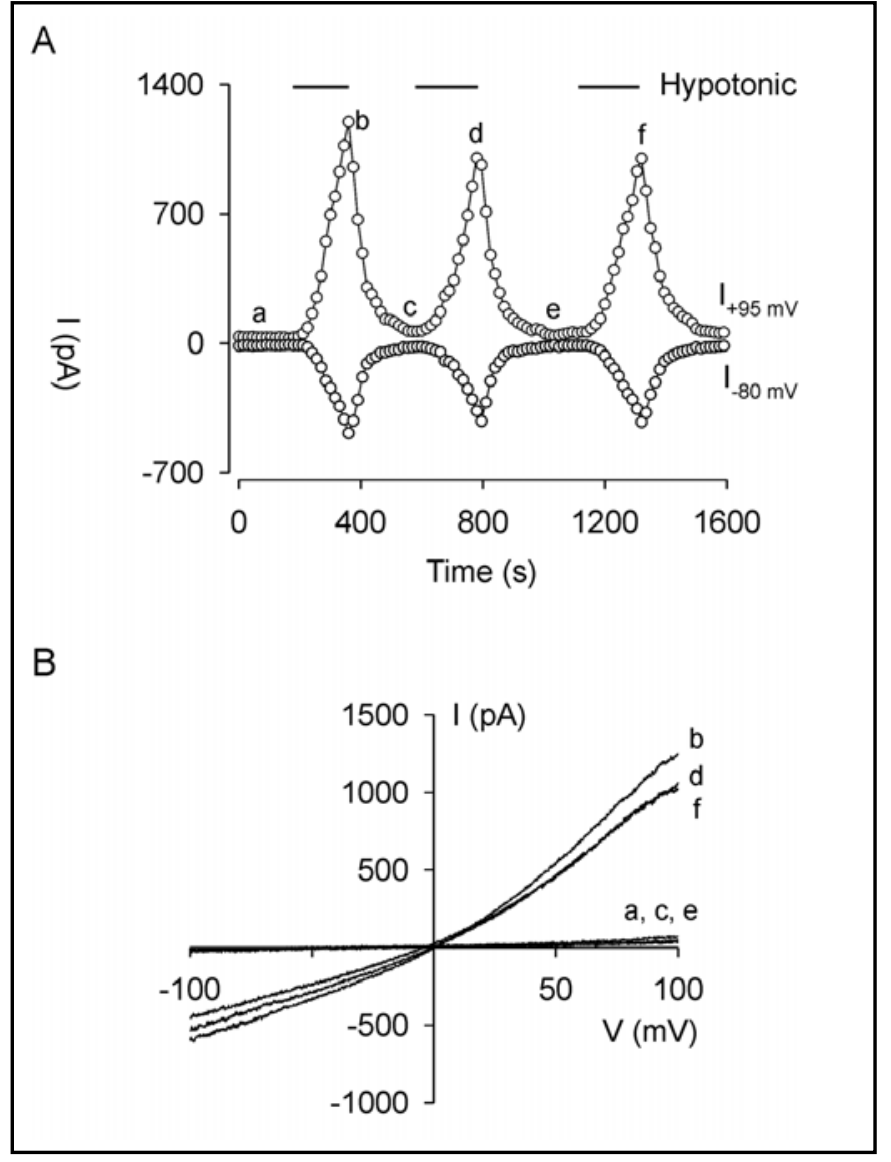

Fig. 3. Repetitive cell swelling activated an outwardly rectifying current. The isotonic bath solution was a modified Krebs solution that contained mannitol with $\left[\mathrm{Ca}^{2+}\right]_{\mathrm{i}}$ buffered at $25 \mathrm{nM}$ with $10 \mathrm{mM}$ BAPTA. The $27 \%$ hypotonic solution was obtained by omitting the appropriate amount of mannitol to reduce osmolarity by $27 \%$. (A) Time course of the volume activated current. The horizontal bars indicate periods of hypotonic exposure. Currents were measured during a small time window at around $+95 \mathrm{mV}$ and $-80 \mathrm{mV}$. (B) The current-voltage (I-V) relationship was measured in the cell shown in (A) with voltage ramps applied at various time points (indicated by letters that correspond to those shown in A). The figure is representative of 5 independent experiments. [Data from [23]].

BALB/c-3T3 fibroblasts [28]. Figure 3 shows the time course of the current measured at +95 and $-80 \mathrm{mV}$, respectively, in an Ehrlich cell that was repetitively exposed to a $27 \%$ hypotonic solution. Panel B shows the currentvoltage $(\mathrm{I}-\mathrm{V})$ relationship. It is clear that there is a very fast activation and deactivation of the current, when the cells are transferred to hypotonic solution and back to isotonic solution respectively.

In EATCs, VRAC was $\mathrm{Ca}^{2+}$ independent, insensitive to niflumic acid, and relatively insensitive to DIDS, but inhibited by tamoxifen [23]. In ELA cells, an acidic di-aryl-urea, NS3728, inhibited VRAC (Fig. 4) with an
$\mathrm{IC}_{50}$ of around $0.4 \mu \mathrm{M}$ [29]. The single channel conductance of VRAC was 3-7 pS in EATC, measured in cell attached patches [30]

\section{Molecular identity}

Despite intensive research, the molecular identity of VRAC remains unknown. We have investigated some candidates for VRAC by testing their expression in ELA cells. In the $\mathrm{ClC}$ family, $\mathrm{ClC}-2$, but not $\mathrm{ClC}-1$ or $\mathrm{ClC}-3$, appeared to be present in ELA cells. The recently cloned $\mathrm{Cl}^{-}$channels, CLIC1 and TMEM16A, were both present in ELA cells. To investigate whether these channels, like VRAC (see below), were differentially expressed during the cell cycle, plasma membrane proteins were isolated by biotinylation. We found that CLIC1 and ClC-2 were down-regulated in the S phase in ELA cells. This was in contrast to observations of VRAC, which was strongly upregulated in the S phase [29, 31]. Moreover, expression of the $\mathrm{Ca}^{2+}$ activated $\mathrm{Cl}^{-}$channel, TMEM16A, did not change in the $\mathrm{S}$ phase.

\section{TMEM16 F}

The mammalian TMEM16 family consists of 10 members, and the TMEM16-A and - B isoforms have been identified as calcium-activated chloride channels (CaCCs). These are responsible for the $\mathrm{CaCC}$ current $\left(\mathrm{I}_{\mathrm{Cl} . \mathrm{Ca}}\right)$ measured in numerous cells [32]. Our group is presently investigating the role of the highly expressed TMEM16F isoform in EATC. The stable knock-down of endogenous mTMEM16F in EATC with micro RNAi resulted in a significant inhibition of the RVD response. However, the contribution of TMEM16F to RVD essentially disappeared when an increase in intracellular $\mathrm{Ca}^{2+}$ during RVD was prevented with BAPTA-AM (Holm et al.,unpublished results). Surprisingly, a knock-down of TMEM16F in EATC actually resulted in 2-3 fold increases in VRAC (Holm et al., unpublished results). Together these observations suggested that TMEM16F was not VRAC; however, mTMEM16F may be part of a macro-molecular complex that is involved in VRAC regulation.

\section{Mechanisms of VRAC activation by cell swelling in EATC and ELA cells}

The swelling -activated $\mathrm{Cl}^{-}$current in EATC is a characteristic VRAC, and it is essentially $\mathrm{Ca}^{2+}$ independent (unaffected by strong $\left[\mathrm{Ca}^{2+}\right]$ buffering with $10 \mathrm{mM}$ EGTA). This current is clearly biophysically different from 
Fig. 4. Effect of the anion channel inhibitor, NS3728, on VRAC in ELA cells. Formula for NS3728 and dose-response curves for the inhibitory effect of NS3728 on VRAC at $-55 \mathrm{mV}$ and $+40 \mathrm{mV}$, as indicated. Currents were measured under hypotonic (190 mOsm) conditions with the fast ramp protocol; inhibition was calculated with the Hill equation ( $n=3-4$ independent experiments at each concentration). [Data from [29]].

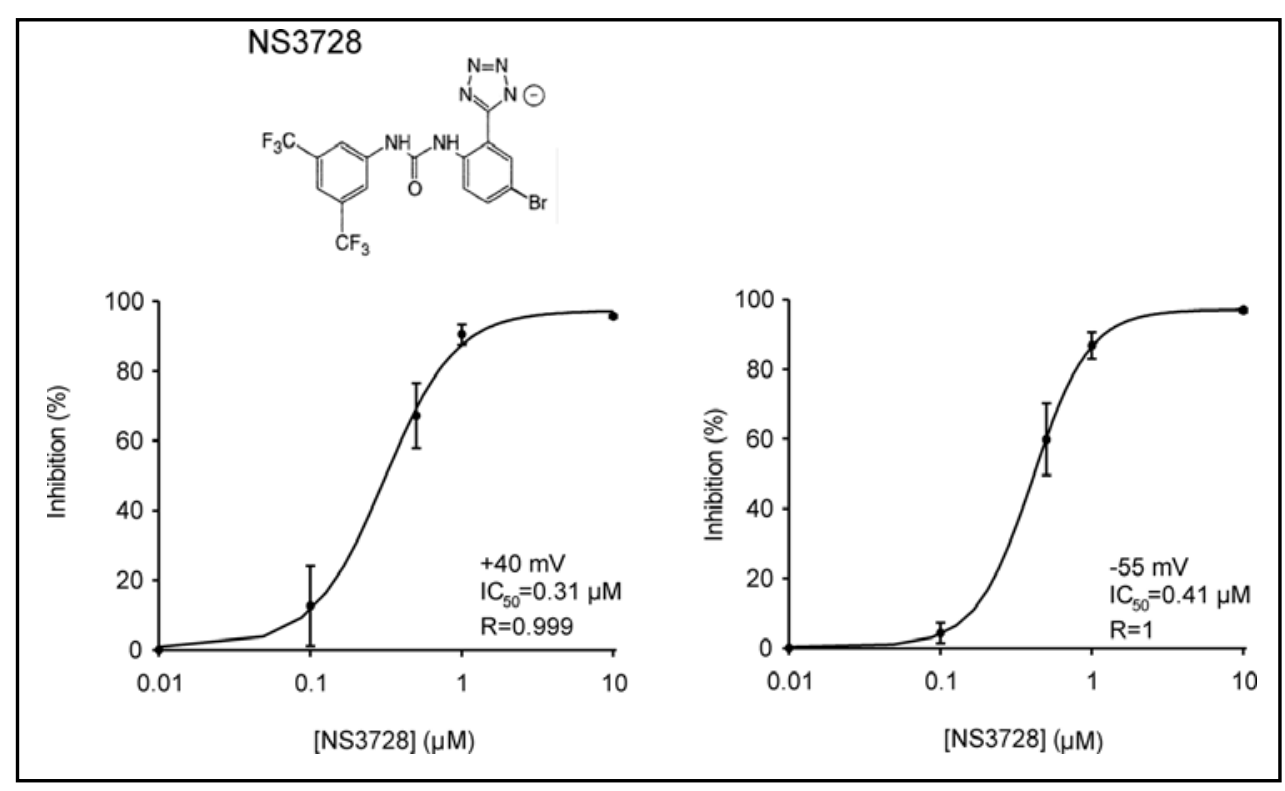

$\mathrm{CaCC}$ [23]. In agreement with this, niflumic acid, which is an inhibitor of $\mathrm{CaCC}_{\mathrm{Ca}}$, did not inhibit RVD, but tamoxifen, an inhibitor of VRAC, completely blocked RVD [33]. Furthermore, no increase in $\left[\mathrm{Ca}^{2+}\right]_{i}$ was observed after cell swelling in the majority of EATC [34]. VRAC in ELA cells and/or in EATC was shown to be controlled by several other factors. These included reactive oxygen species [35] the cytoskeleton [36], and the membrane lipid composition; i.e., the cholesterol content $[24,37]$ and the polyunsaturated fatty acid content [38].

Cholesterol modulates the volume-regulated anion current in ELA cells via effects on Rho and F-actin

Reduction in cellular cholesterol content (44\%) resulted in a significant potentiation of VRAC in ELA cells (Fig. 5) after a modest (15\%), but not after a severe (36\%) reduction in extracellular osmolarity [24]. Levitan and coworkers [37] pointed out that this was consistent with the notion that cholesterol depletion caused an increase in the fraction of open channels, rather than an effect on the single channel conductance. Conversely, an increase in cellular cholesterol content $(\sim 4 \%)$ had no effect on VRAC in ELA cells. This suggested that the cholesterol effect on VRAC was maximal in ELA cells with physiological cholesterol content. Cholesterol depletion also activated a VRAC-like current in the absence of cell swelling [24]. This suggested that changes in cholesterol content somehow affected the volume signal per $s e$; perhaps by increasing the number of open VRAC channels. The identity of this putative volume- and cholesterol-sensitive parameter is unknown, but we found that the cholesterol-induced increases in maximal VRAC

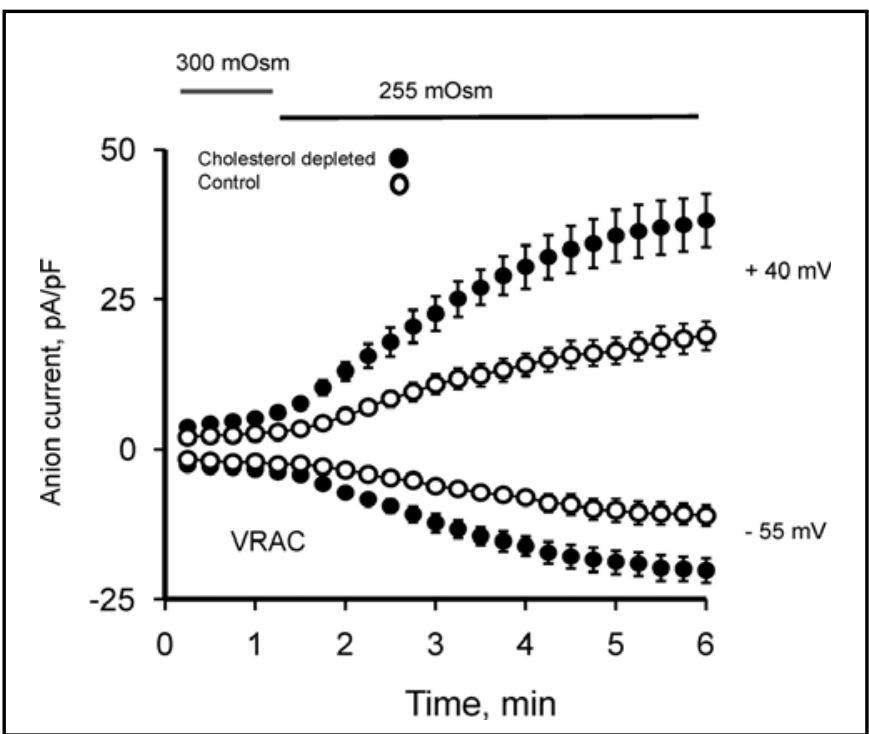

Fig. 5. Effect of cholesterol depletion on VRAC in ELA cells under hypotonic conditions. Cells were cholesterol-depleted by prexposure to empty Methyl- $\beta$-cyclodextrin (M $\beta C D)$. At time $=1 \mathrm{~min}$, the medium was shifted to a hypotonic medium (225 mOsm). The VRAC was recorded with the whole cell patch clamp technique at voltages of $-55 \mathrm{mV}$ and $+40 \mathrm{mV}$ with a fast ramp-protocol. [Data from [24]].

current and activation rate were dependent on F-actin and ROK, respectively. In contrast, changes in cellular $\operatorname{PtdIns}(4,5) \mathrm{P}_{2}$ had no effect on VRAC [24].

Therefore, a candidate volume- and cholesterol-sensitive parameter might be membrane stiffness, which is known to be dependent on cortical F-actin. This hypothesis would be consistent with the observation that cholesterol depletion eliminated the swelling-induced decrease in cortical and stress fibre-associated F-actin in ELA cells. 
In other words, cell stiffness was increased after cholesterol depletion. F-actin disruption by latrunculin B (LB) in ELA cells potentiated the isotonic VRAC current induced by cholesterol depletion; however, it prevented the cholesterol depletion-induced increase in maximal current magnitude after cell swelling. This suggested that Factin integrity was required for the cholesterol-depletioninduced increase in VRAC magnitude under hypotonic conditions, but also for limiting isotonic VRAC activity in cholesterol-depleted cells [24]. This scenario resembles the shrinkage-induced activation of the $\mathrm{Na}^{+}-\mathrm{K}^{+}-2 \mathrm{Cl}^{-}$ cotransporter, $\mathrm{NKCC} 1$. There, F-actin integrity was required both to maintain NKCC1 silence, under isotonic steady-state conditions, and for shrinkage-induced activation of NKCC1 [39]. Rho activity was decreased in osmotically swollen cells, and this reduction was prevented by cholesterol depletion. Cholesterol depletion also increased Rho activity under isotonic conditions.

Taken together, these results suggested that, in ELA cells, F-actin and the Rho-Rho kinase pathway might modulate VRAC activity. Cholesterol depletion thus increased VRAC currents, at least in part, by preventing the hypotonicity-induced decrease in Rho activity and promoting $\mathrm{F}$-actin polymerization [24]. In this context, it should be mentioned that VRAC did not appear to be activated by membrane stretch in EATC [30] or in other cell types [15]

\section{Other changes in lipids}

Membrane fluidity can be altered by changes in lipids other than cholesterol; for example, by changes in the saturation of fatty acids. Two weeks of dietary n-3-rich fish oil $(7.5 \%, \mathrm{wt} / \mathrm{wt})$ increased the ratio of eicosapentaenoic acid to arachidonic acid in EATC phospholipids compared with an olive oil control diet [38]. We showed that an increase in the membrane content of eicopentaenoic acid with dietary fish oil accelerated RVD (Fig. 6) and increased swelling -activated $\mathrm{Cl}^{-}$and $\mathrm{K}^{+}$ permeabilities [38].

\section{ROS}

In various cell types, ROS production is increased within the first minute following hypotonic exposure [7]. ROS are also involved in the swelling-induced activation of VRAC; e.g., in liver cells [40], HeLa cells [41], and rabbit ventricular myocytes [42]. A ROS-induced anion current has been related to osmotic stretching of $\beta_{1}$ integrin in, e.g., rabbit ventricular myocytes [42] ). Thus, we raised the question of whether ROS might play an equivalent role in adherent/nonadherent cells.

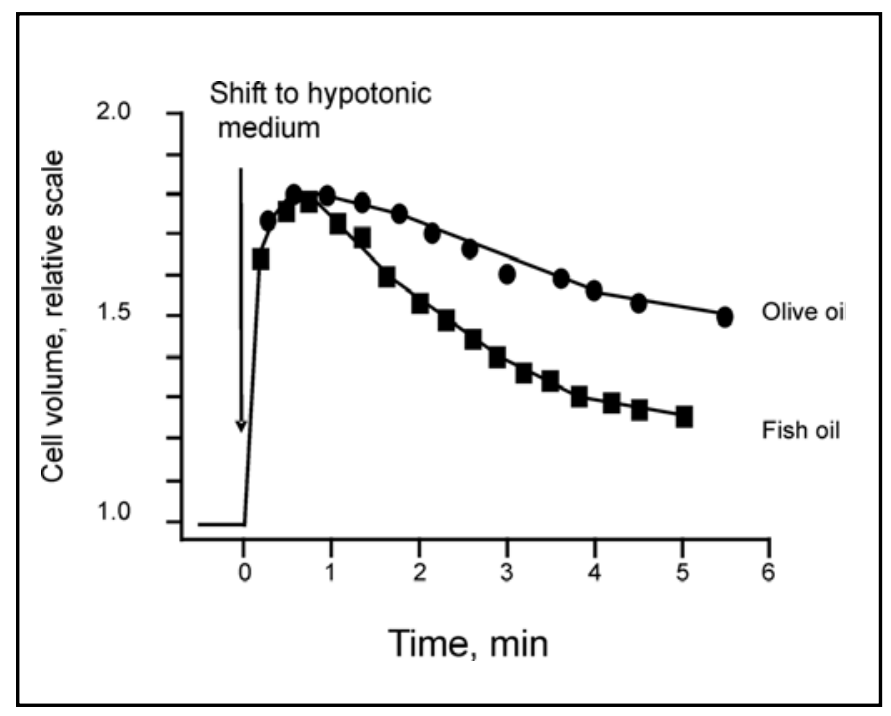

Fig. 6. Effect of lipid modification on the RVD response in EATCs. The effect of dietary fish oil/olive oil on RVD in EATCs was estimated. EATCs were isolated from mice after two weeks on a diet supplemented with n-3 fish oil (MaxEPA) or virgin olive oil as a control. The cell volume was followed over time under hypotonic conditions (150 mOsm) with the Coulter counter technique. [Data from [38]].

Addition of $\mathrm{H}_{2} \mathrm{O}_{2}(0.5 \mathrm{mM})$ to nonadherent EATCs resulted in a substantial $(22 \pm 1 \%)$ reduction in cell volume within $25 \mathrm{~min}$. However, in EATC, $\mathrm{H}_{2} \mathrm{O}_{2}$ activates electroneutral $\mathrm{KCl}$ cotransport, not $\mathrm{K}^{+}$and $\mathrm{Cl}^{-}$channels [35]. Addition of $\mathrm{H}_{2} \mathrm{O}_{2}$ to hypotonically swollen EATC accelerated the RVD, but there was no additional increase in $\mathrm{K}^{+}$and $\mathrm{Cl}^{-}$conductances. In contrast, addition of $\mathrm{H}_{2} \mathrm{O}_{2}$ to adherent ELA cells increased the $\mathrm{K}^{+}$and $\mathrm{Cl}^{-}$conductances after hypotonic cell swelling (Fig. 7). Hence, $\mathrm{H}_{2} \mathrm{O}_{2}$ could induce $\mathrm{KCl}$ cotransport and activate $\mathrm{K}^{+}$and $\mathrm{Cl}^{-}$ channels in nonadherent and adherent cells, respectively [35]. It should be noted that the preferential reliance on $\mathrm{KCl}$ cotransport versus $\mathrm{K}^{+}$and $\mathrm{Cl}^{-}$channels in nonadherent EATC and adherent ELA cells does not reflect a down regulation of the expression of $\mathrm{KCl}$ in ELA cells or of TASK-2 in EATC as nonadherent as well as adherent cells express mRNA coding for the cotransporters $\mathrm{KCC} 1,3$ and 4 as well as mRNA for TASK-2 [35]. As a ROS-induced anion current as mentioned above has been related to osmotic stretching of $\beta_{1}$-integrin [42] we are at the moment focusing on the differences in integrins between EATC and ELA cells . 
Fig. 7. Effect of $\mathrm{H}_{2} \mathrm{O}_{2}$ on ion currents in ELA cells. The $\mathrm{I}_{\mathrm{K}}$ and $\mathrm{I}_{\mathrm{Cl}}$ were measured with the whole cell patch-clamp technique on ELA cells adhered to glass coverslips in the presence or absence (control) of $\mathrm{H}_{2} \mathrm{O}_{2}(0.5 \mathrm{mM})$. The bath solution contained $28 \mathrm{mM} \mathrm{NaCl}, 62 \mathrm{mM} \mathrm{Na}$-gluconate, and it was adjusted to $300 \mathrm{mOsm}$ with d-mannitol. At the times indicated by the bar, hypotonic conditions were applied by omitting d-mannitol from the bath solution. The membrane potential was clamped at either the $\mathrm{Cl}^{-}(-6 \mathrm{mV})$ or the $\mathrm{K}^{+}(-68 \mathrm{mV})$ equilibrium potential to isolate the $\mathrm{K}^{+}$or $\mathrm{Cl}^{-}$current, respectively. [Data from [35]].

\section{Swelling -activated $K^{+}$channels}

Cell swelling-induced activation of a $\mathrm{K}^{+}$leak pathway was first described in lymphocytes and EATC [19, 43]. Later, different $\mathrm{K}^{+}$channels in different cell types have been shown to be implicated in RVD $[6,7]$. The volume-sensitive $\mathrm{K}^{+}$channel in EATC is the TWIK-related, acid-sensitive $\mathrm{K}^{+}$channel-2 (TASK-2), which belongs to the two-pore domain channel family [44]. TASK2 is a ChTX- insensitive, clofilium sensitive, $\mathrm{Ca}^{2+}$ independent channel [45], with a permeability sequence of: $\mathrm{K}^{+}>\mathrm{Rb}^{+}>>\mathrm{Cs}^{+}, \mathrm{NH}^{4+}, \mathrm{Na}^{+}, \mathrm{Li}^{+}$[46-48]. In EATC, TASK-2 is highly sensitive to external $\mathrm{pH}$ [48]. In addition, TASK-2 has been associated with apoptotic volume decreases in EATC following cisplatin exposure [49]. Recently, TASK-2 has been ascribed a role in T-cell activation [50]; we have found that TASK-2 was up-regulated in activated T-cells, on both the protein and mRNA levels. Thus, we are using siRNA to study the potential role of TASK - 2 in proliferation and in volume regulation of CD3/CD28-activated T cells (Stroem et al., unpublished results) .

\section{Mechanisms of TASK-2 activation by cell swelling}

The TASK- 2 channel is not directly stretch activated [30]. In a series of papers, we have shown that its activation involved the cysteinyl leukotriene $\mathrm{D}_{4}\left(\mathrm{LTD}_{4}\right)[51$ 53], tyrosine phosphorylation [54] and GTP binding proteins [55].

\section{LTD4}

A role for leukotriene $\mathrm{D} 4\left(\mathrm{LTD}_{4}\right)$ in the activation of TASK-2 after cell swelling in EATC was evidenced by the following observations. (i) In $\mathrm{Ca}^{2+}$ - free media, 3 $\mathrm{nM} \mathrm{LTD}_{4}$ accelerated the RVD response in the absence
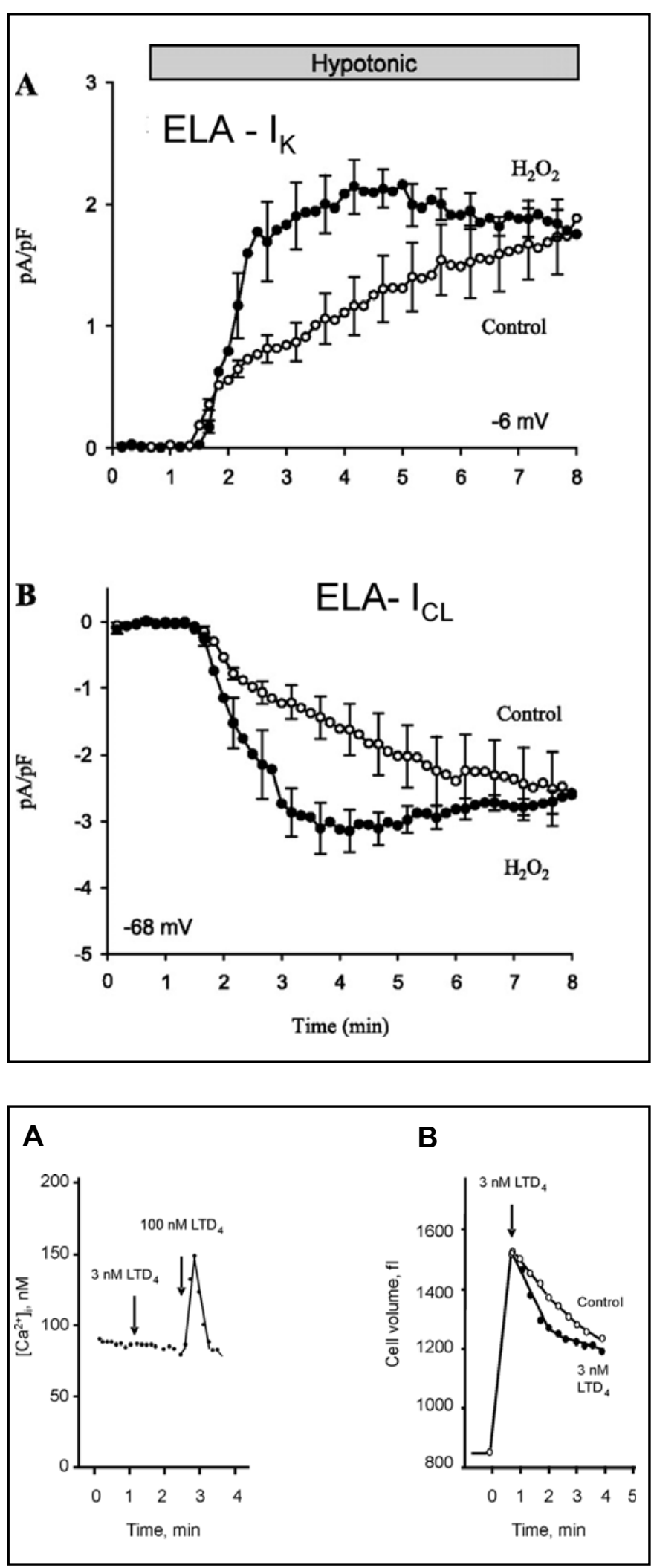

Fig. 8. $\mathrm{LTD}_{4}$ plays a role in RVD that is not correlated with increases in $\left[\mathrm{Ca}^{2+}\right]_{\mathrm{i}}(\mathrm{A})$ The effect of low $(3 \mathrm{nM})$ and high $(100$ $\mathrm{nM})$ doses of $\mathrm{LTD}_{4}$ on $\left[\mathrm{Ca}^{2+}\right]_{\mathrm{i}}$ in EATC was investigated with FURA2-fluorescence. [Data from [51]]. (B) Effect of low dose $\mathrm{LTD}_{4}(3 \mathrm{nM})$ on RVD in EATC was assessed by the Coulter technique. [Data from [51]]. 
of an increase in $\left[\mathrm{Ca}^{2+}\right]_{\mathrm{i}}$ [51] (Fig. 8 A, B). (ii) Cell swelling activated phospholipase cPLA ${ }_{2}$ [56] (Fig. 9) and stimulated synthesis of $\mathrm{LTC}_{4} / \mathrm{LTD}_{4}$ [57]. (iii) Under isotonic conditions, $\mathrm{LTD}_{4}$ activated two $\mathrm{K}^{+}$effluxes; one was a ChTX-sensitive, $\mathrm{Ca}^{2+}$-activated $\mathrm{K}^{+}$efflux and the other, similar toTASK-2, was ChTX-insensitive [52]. (iv) LTD $(5 \mathrm{nM})$ activated a whole cell $\mathrm{K}^{+}$current that was similar to TASK-2 in conductance, I/V relation, and pharmacological profile [53]. Finally, $(v)$ addition of LTD $_{4}$ reduced the activation time of TASK-2 after cell swelling [53]. These observations could be explained in tentative model (Fig.10) proposed for the role of LTD4 in the RVD of EATC [10]. This hypothesis holds that cell swelling results in activation and translocation of $\mathrm{CPLA}_{2} \alpha$ to the nucleus (Fig. 9A), where it mobilizes AA from the $s n-2$ position of the inner nuclear membrane phospholipids (Fig. 9B). With the involvement of the Five Lipoxygenase Activating Protein (FLAP), 5-Lipoxygenase (5-LOX), and $\mathrm{LTC}_{4}$ synthase, AA is converted to $\mathrm{LTC}_{4}$, which is transported out of the cell; there, it is converted to $\mathrm{LTD}_{4}$ by $\gamma-$ glutamyl transpeptidase. $\mathrm{LTD}_{4}$ binds with an $\mathrm{EC}_{50}$ value of $2 \mathrm{nM}$ to a putative, MK-571 insensitive CysLT receptor [52] and activates $I_{K, v o l}$ [53] (see Fig 10). In contrast to the volume sensitive $\mathrm{K}^{+}$channel, the volumesensitive $\mathrm{Cl}^{-}$channel is independent of $\mathrm{LTD}_{4}$ in EATC [53].

\section{$\mathrm{Ca}^{2+}$-potentiation}

At concentrations above $10-20 \mathrm{nM}, \mathrm{LTD}_{4}$ binding to the cloned CysLT 1 receptor [58] activated the $\mathrm{Ca}^{2+}$ signalling pathway. This will activate the $\mathrm{Ca}^{2+}$-dependent $\mathrm{I}_{\mathrm{K}}$ channel [30] and the $\mathrm{Ca}^{2+}$-dependent $\mathrm{Cl}^{-}$channel ( $\mathrm{CaCC}$ ) [23], which will potentiate the RVD response (Fig. 10).

\section{External ATP}

ATP released to the extracellular medium during cell swelling can similarly contribute to activation of both $\mathrm{Ca}^{2+}$ dependent $\mathrm{K}^{+}$channels and CACCs. Thus, ATP also potentiated the RVD response, as shown in rat hepatoma cells [59]. In EATC, we found that ATP stimulated PY receptors [60], which resulted in an increase in $\left[\mathrm{Ca}^{2+}\right]_{\mathrm{i}}$ and activation of charybtotoxin-sensitive $\mathrm{K}^{+}$channels.

\section{Tyrosine phosphorylation}

Figure 11 shows that tyrosine phosphorylation plays a central role in the activation of TASK-2 during cell swelling and RVD. In EATC, RVD is rate limited by $I_{\mathrm{K}, \mathrm{vol}}$. This indicates that the inhibition of RVD reflected inhibition of TASK-2. We found that Genistein (a tyrosine ki-

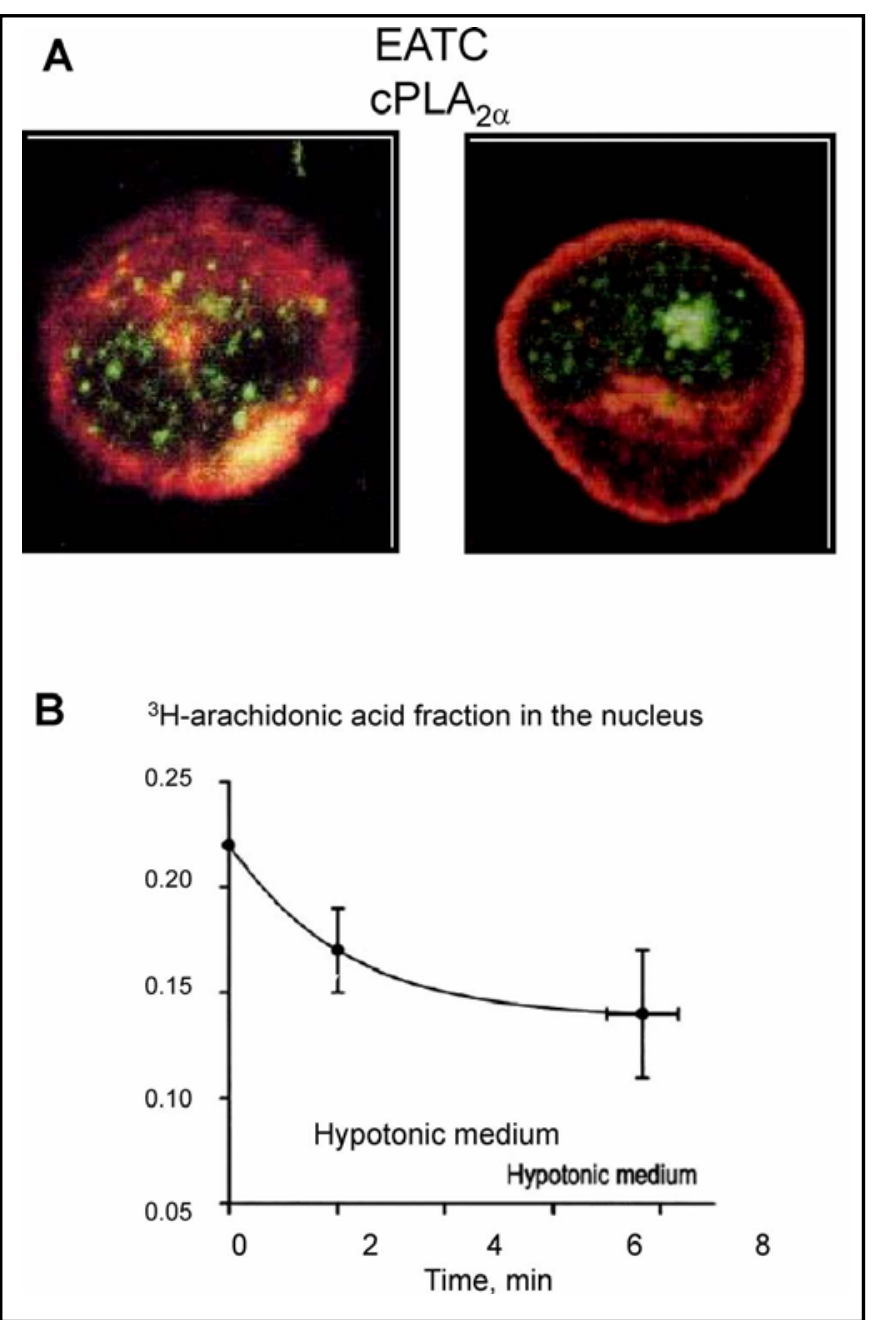

Fig. 9. Cell swelling activates cytoplasmic phospholipase A2 $\alpha$ $\left(\mathrm{cPLA}_{2 \alpha}\right)$ in EATC. EAT cells (panel A) were exposed to isoosmotic (left) or hypotonic solution (150 mOsm; right) for 1 minute and fixed for confocal laser scanning microscopy (CLSM). The cell were labeled with rabbit anti-cPLA ${ }_{2 \alpha}$ and visualized using a FITC-conjugated antibody (green), The plasmamembrane was visualized using tetramethyl-rhodamineconjugated agglutinin (red). B. EAT cells were preloaded for 2 hours with ${ }^{3} \mathrm{H}$-AA washed and exposed to isoosmotic or hyposmotic $(150 \mathrm{mOsm})$ solutions. The fraction of ${ }^{3} \mathrm{H}-\mathrm{AA}$ in the nucleus was estimated as ${ }^{3} \mathrm{H}$-activity in the nuclear fraction divided by the activity in the nuclear plus cytosolic fraction. The nuclei were purified (Sigma NUC-201 nuclei isolation kit). Data from [56]

nase inhibitor) inhibited the rate of RVD by almost $90 \%$ prolonging the osmotic phase a lot (Fig 11A), and the tyrosine phosphatase inhibitor monoperoxo(picolinato)oxo-vanadate $(\mathrm{mpV}(\mathrm{pic}))$ shifted the volume set point to a lower cell volume for re-closing the channel [54]. When the tyrosine phosphatase inhibitor was added together with the tyrosine kinase inhibitor, channel activation was not inhibited (Fig. 11B). 


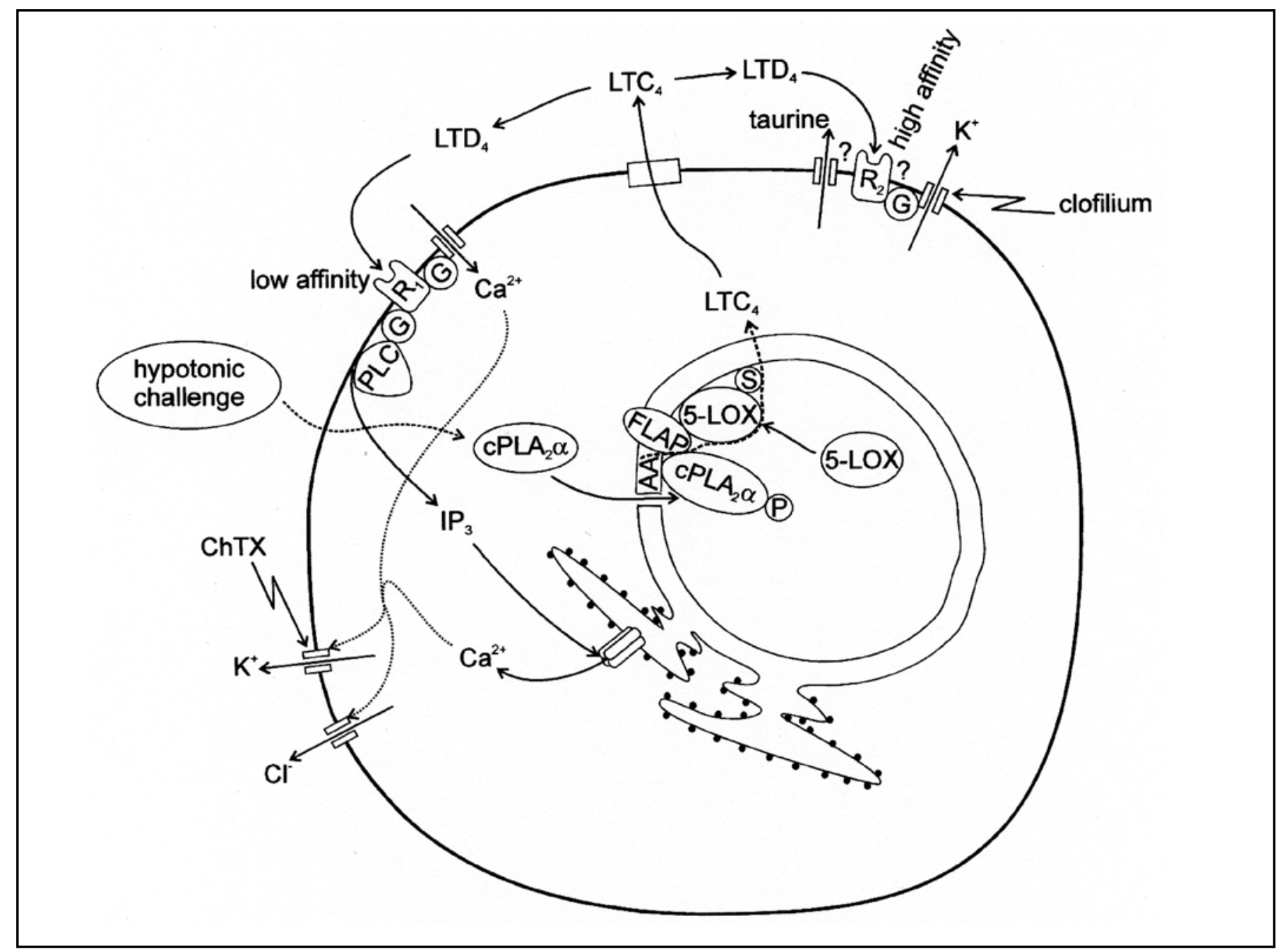

Fig. 10. Proposed model for intracellular signaling involved in activation of TASK-2 after hypotonic swelling of EATC. Upon cell swelling, $\mathrm{CPLA}_{2} \alpha$ translocates to the inner nuclear membrane and becomes activated by phosphorylation. Arachidonic acid released by $\mathrm{cPLA}_{2} \alpha$ is converted to $\mathrm{LTC}_{4}$ by the combined action of 5-LOX and the $\mathrm{LTC}_{4}$ synthase. LTC 4 is released to the extracellular space and converted to $\mathrm{LTD}_{4}$. At low concentrations $\mathrm{LTD}_{4}$ activates the clofilium- and volume-sensitive TASK-2 channel. This effect might be via a receptor and a G-protein coupled process. At higher concentrations LTD $_{4}$ binds to the CysLT 1 receptor $\left(\mathrm{R}_{1}\right)$ and activates the $\mathrm{Ca}^{2+}$ signaling pathway. The increase in $\left[\mathrm{Ca}^{2+}\right]_{i}$ induced by $\mathrm{CysLT}_{1}$ receptor activation activates ChTX-sensitive $\mathrm{K}^{+}$channels and CACCs. See text for further details. Reproduced from [104] with permission.

In agreement with this, swelling -activated $\mathrm{K}^{+}$efflux was impaired by genistein and enhanced by $\mathrm{mpV}$ (pic) [54]. Thus, tyrosine kinases appeared to be involved in the activation of TASK-2 during cell swelling, and tyrosine phosphatases appeared to be involved in inactivation of the channel. Overexpressing TASK-2 in human embryonic kidney (HEK)-293 cells resulted in an acceleration of RVD and a lower volume set point compared to wild type cells. The Janus kinase inhibitor cucurbitacin inhibited RVD by $60 \%$ (Fig. 11B). This suggested that the JAK/STAT pathway was upstream from the swelling-induced phosphorylation of TASK-2 [54]. Finally, a cell swelling-induced, time-dependent, tyrosine phosphorylation of TASK-2 in HEK-293 cells overexpressing TASK-2 channels was observed with anti-phosphotyrosine immunoblotting (Fig. 11C) [54]. The tyrosin phosphorylation of the channel was evident within the period 1 to 10 min after hypotonic treatment suggesting that TASK2 is activated for at least that period of time. This is in agreement with the observation that the rate constant calculated from $\mathrm{K}^{+}$efflux data was high and unaltered in the time period 1 to $10 \mathrm{~min}$ after hypotonic exposure. When tyrosin dephosphorylation will again close the channel cannot be estimated from the present experiment. 
Fig. 11. Role of tyrosine kinases in swell-activation of TASK2 and RVD. EATCs were preincubated with or without the tyrosine kinase inhibitor genistein $(371 \mu \mathrm{M})$ for $45 \mathrm{~min}$. (A) Cells were transferred (time $=0)$ to hypotonic medium $(150 \mathrm{mOsm})$, with or without genistein $(371 \mu \mathrm{M})$. Cell volume was followed over time in a Coulter Counter. (B) RVD was estimated with the Coulter counter after a 45 min preincubation in genistein (371 $\mu \mathrm{M})$ with or without the tyrosine phosphatase inhibitor ( $\mathrm{mpV}$; $10 \mu \mathrm{M}$ ), or after a $4 \mathrm{~h}$ preincubation with the JAK2 inhibitor cucurbitacin (Cucur., $10 \mu \mathrm{M}$ ). The initial rate of RVD was measured following hypotonic exposure $(150 \mathrm{mOsm})$, and the rates are expressed relative to control. All inhibitors were present during RVD estimation. The results represent the mean of 6 (control), 4 (genistein), 3 (genistein plus $\mathrm{mpV}$ ), or 3 (cucurbitacin) experiments. *Significantly different from the control value. (C) Tyrosine-phosphorylation of TASK-2 was measured in cells subjected to either isotonic or hypotonic conditions. HEK-293 cells were transfected with a pcDNA3.1/ myc-His vector that carried the TASK-2 sequence. At various incubation times $(1,5,10 \mathrm{~min})$, cells were lysed, TASK-2 channels were precipitated, then separated by SDS-PAGE, and Western blotted. TASK-2 expression and the level of tyrosinephosphorylation (pY100) was visualized with the appropriate labelled antibodies. The specific activity for tyrosine-phosphorylated TASK-2 was the ratio between the pY100 band intensity and the TASK-2 band intensity. The ratio derived under hypotonic conditions is shown relative to the ratio derived under isotonic conditions. Values are means from 8,9 , and 6 sets of experiments taken at times 1,5 , and $10 \mathrm{~min}$, respectively. *significant increase compared to isotonic conditions (t-test, $\mathrm{p}<0.05)$. [Data from [54]]. Figure reproduced from [105] with permission.

\section{The volume sensor(s)}

A central question, which we recently reviewed in detail (see [7, 61]), is how cells sense volume changes, and how this sensing is transduced; e.g., to the volume regulatory $\mathrm{K}^{+}$and $\mathrm{Cl}^{-}$channels. The potential mechanisms for cellular volume sensing can be grouped into four categories, including (i) macromolecular crowding [62, 63], (ii) changes in cellular ionic strength [64], (iii) changes in concentrations of specific ions [65], and (iv) mechanical changes in the plasma membrane lipid bilayer and/or the cytoskeleton, partly via the interactions between receptors and adhesion proteins [7]. The first three points have not been investigated in EATC or ELA cells; for the last point, the most current knowledge was discussed above in the activation of VRAC and TASK-2. Thus, I shall now briefly discuss changes in the cytoskeleton.

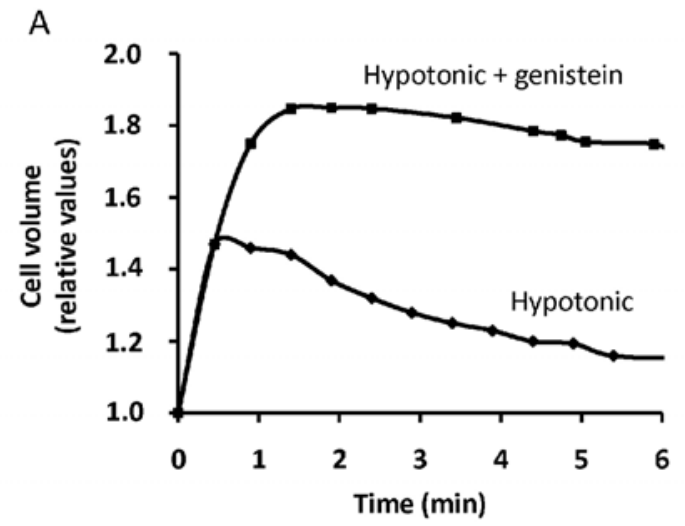

B
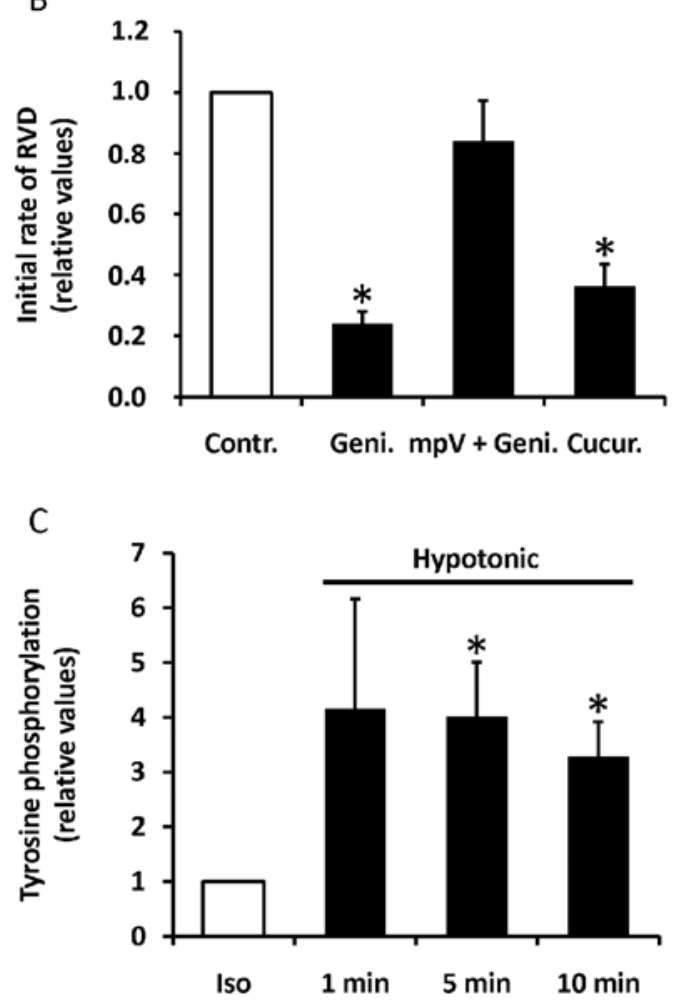

The cytoskeleton in osmosensing

In most cells, osmotic swelling results in a net decrease in actin polymerization. We also found this in nonadherent EATC with a quantitative F-actin assay and confocal laser scanning microscopy of rhodamine-phalloidin labelled cells [66]. In EATC, F-actin was localized to the cortical region, and it appeared to form a ring. Hypotonic cell swelling reduced this cortical F-actin ring within the first min after osmotic challenge (Fig. 12), moreover, during cell swelling, the cellular content of F-actin was significantly reduced [66].

The swelling-induced decrease in F-actin may be regulated by MLCK in EATC $[67,68]$. In EATC, we 


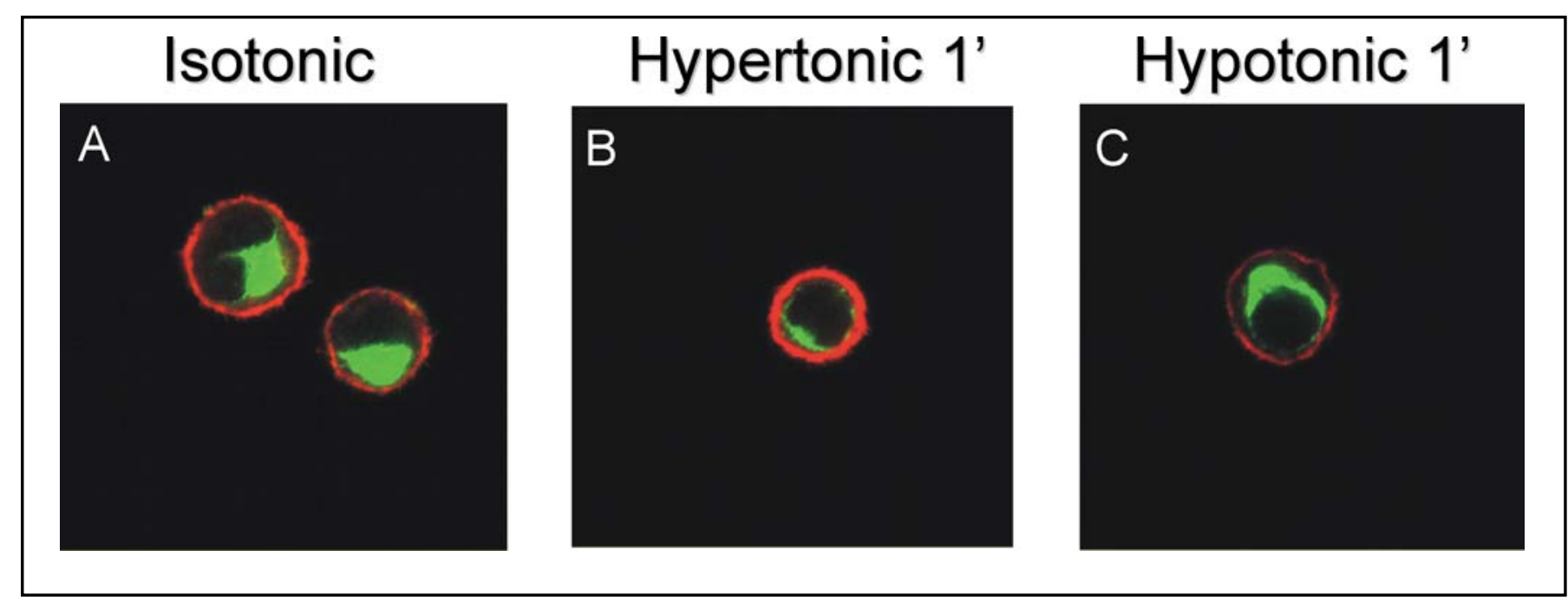

Fig. 12. Osmotic shrinkage and swelling effects on F-actin organization and myosin IIB distribution. At time $=0$, Ehrlich ascites tumor cells were diluted to a cytocrit of $2 \%$ under isotonic, hypertonic, or hypotonic conditions, and 1-ml aliquots were removed for fixation. Cells were permeabilized in $0.1 \%$ saponin and incubated with the anti-myosin II antibody, CMII23 (1:200). Next, a FITC-conjugated goat antimouse secondary antibody (1:100) was added. To visualize F-actin, Rhodamine phalloidin (2 U/ml) was included in the incubation buffer with the secondary antibody, The cells were viewed with a confocal laser scanning microscope. Images are representative cells from at least three independent experiments for each condition, at time $=0$ (isotonic) or time $=1 \mathrm{~min}\left(1^{\prime}\right)$. For each situation, myosin II labelling is shown in green and rhodamine phalloidin labelling of F-actin is shown in red. [Data from [67]].

showed that myosin II was rapidly translocated to the Golgi/perinuclear region upon hypotonic swelling and to the cortical ring during hypertonic shrinkage [67] (Fig. 12). Moreover, $G$ proteins of the Rho family are highly sensitive to cell volume changes and are involved in cytoskeletal rearrangements that occur during volume regulation. Thus, similar to F-actin, Rho activity rapidly increased after hypertonic cell shrinkage in ELA cells [69-71] and decreased in osmotically swollen ELA cells [36].

To determine whether changes in F-actin during cell swelling played a functional role in the RVD response of EATC, we pre-treated cells with F-actin-disrupting agents, cytochalasin and latrunculin. It should be noted that cytochalasin has highly variable effects on F-actin in intact cells; the effects depend on the cytochalasin concentration, the isoform used, and the cell type tested [66, 72]. For example, in EATC, we found that low concentrations $(0.5 \mu \mathrm{M})$ of the cytochalasins tested $(\mathrm{CB}, \mathrm{CD}$, $\mathrm{CE}$, and chaetoglobosin $\mathrm{C}[\mathrm{CGC}]$ ) resulted in significant F-actin depolymerization; however, a high concentration $(10 \mu \mathrm{M})$ did not depolymerize F-actin. The addition of $0.5 \mu \mathrm{M}$ CB inhibited RVD in EATCs, but none of the other cytochalasins tested had an effect. It was suggested that the CB effect was related to its known activity of

Ion Channels in Regulatory Volume Decrease in Ehrlich Cells severing F-actin, which could lead to an increase in the cellular pool of "short" actin filaments [73]. Data that involves cytochalasin treatment must, in general, be interpreted with caution; specifically, because at least some of the cytochalasins have effects that are unrelated to cytoskeletal integrity $[66,72]$.

It has been suggested that the actin-based cytoskeleton regulates nearly all the transporters and channels that mediate RVD or RVI in EATC and ELA cells. This includes swelling -activated $\mathrm{Cl}^{-}$channels [36], swelling activated $\mathrm{K}^{+}$channels [74], and the shrinkage activated NKCC1 $[39,75,76]$

\section{Volume-sensitive ion channels in cell pro- liferation, migration, and apoptosis}

\section{Cell proliferation}

It is well known that cell proliferation is stimulated by cell swelling and inhibited by shrinkage [77]. We found that, during the $\mathrm{S}$ phase, ELA cells swell by taking up ions and water [31]. Actually, prior to the $\mathrm{S}$ phase, in the $\mathrm{G}(0)-\mathrm{G}(1)$ phase transition, the cellular content of $\mathrm{Na}^{+}$ and $\mathrm{Cl}^{-}$is reduced; then, in the $\mathrm{S}$ phase, cells increase their uptake of both ions and water concomitantly. In fact, 
Fig. 13. VRAC antagonists inhibit cell proliferation. The anion channel inhibitors, (A) DIDS, (B) niflumic acid, (C) NS3728, and (D) tamoxifen were tested for effects on cell proliferation in a BrdU incorporation assay. Cells were pre- incubated for $24 \mathrm{~h}$ with the indicated inhibitor. The $\%$ inhibition was measured at different inhibitor concentrations, and compared to the BrdU incorporation in control, untreated cells. *mean is significantly different from the control $(P<$ $0.05) ; n=3-8$. [Data from [80]]
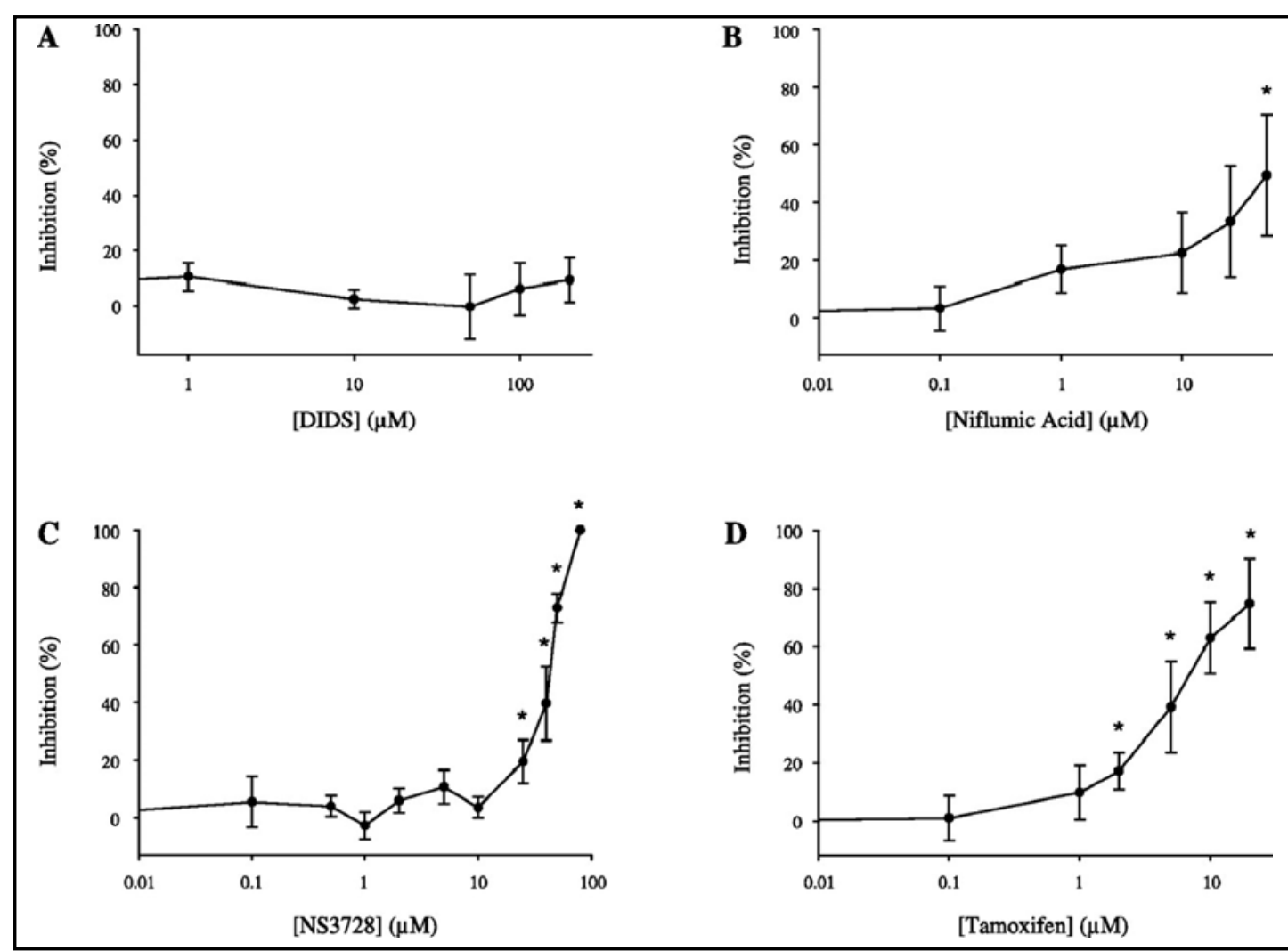

Fig. 14. Cell cycle-dependent changes in maximal VRAC activity in ELA cells. Whole-cell patch-clamp measurements of the maximal $\mathrm{Cl}^{-}$current activated by cell swelling in ELA cells during the G0, G1, or S phase of the cell cycle. Currents were measured after exposure to hypotonic extracellular solution (190 mOsm) in nominally zero $\left[\mathrm{Ca}^{2+}\right]_{\mathrm{i}}$ (no added $\mathrm{Ca}^{2+}$, and 10 $\mathrm{mM}$ EGTA in the pipette solution). The voltage was held at 0 $\mathrm{mV}$, and voltage ramps were applied from -50 to $+150 \mathrm{mV}$. In the ramps, voltage steps were applied at $15 \mathrm{~s}$ intervals and held for $2.6 \mathrm{~s}$. Data represent the I-V relationships based on the mean current density obtained from six to nine different cells in each cell cycle phase; error bars are SEMs. Current densities in the G0 and $\mathrm{S}$ phases are significantly different from that in G1 phase; $* P<0.05 ; * * * P<0.001$. Current densities in $\mathrm{S}$ phase are also significantly different from those in G0 phase $(P<0.05$, not illustrated). [Data from [29]]

cell proliferation can be inhibited by substituting $\mathrm{Na}^{+}$with $\mathrm{NMDG}^{+}$, substituting $\mathrm{Cl}^{-}$with an impermeable anion, or by inhibiting either $\mathrm{Cl}^{-}$channels or NHE1[31].

\section{Channels involved}

Ion channels and transporters are important for cell proliferation in several cell types [78]; furthermore, $\mathrm{Na}^{+}$, $\mathrm{K}^{+}$, and $\mathrm{Cl}^{-}$channels are dysregulated in many cancer cells [79]. In ELA cells, we have mainly studied the role

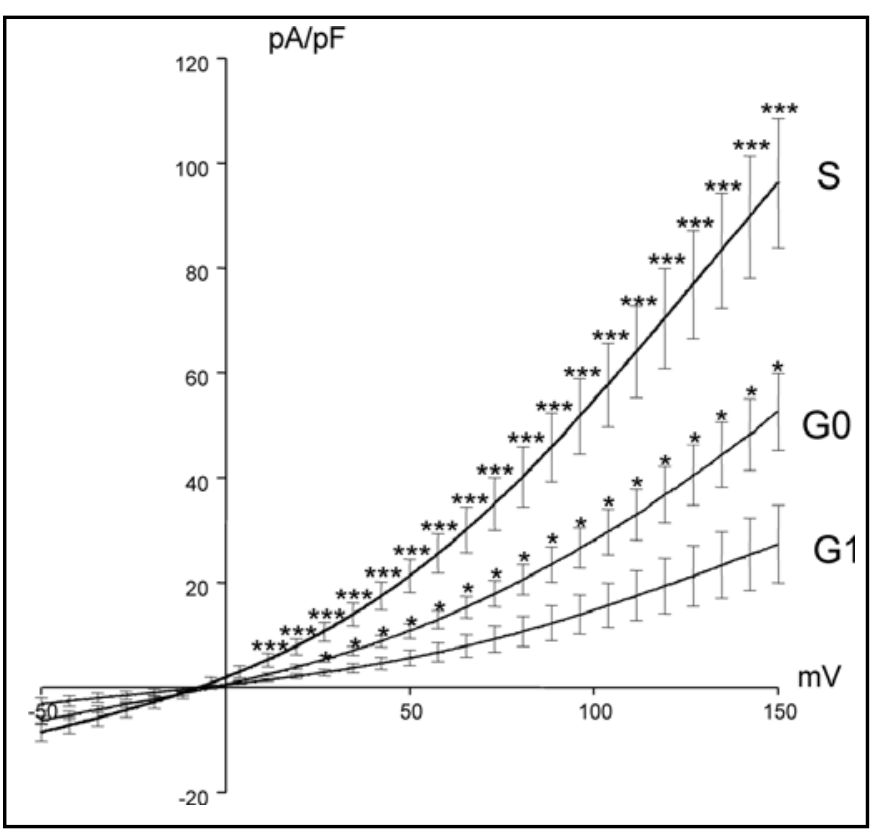

of $\mathrm{Cl}^{-}$channels $[29,80]$. The role of $\mathrm{Cl}^{-}$channels in cell cycle control was demonstrated by the fact that $\mathrm{Cl}^{-}$channel blockers inhibited cell proliferation in several cell types, including ELA cells [29, 81, 82]. In ELA cells we found that the high-affinity anion channel inhibitor, NS3728 (an acidic di-aryl-urea), which blocks VRAC and CaCC channels in ELA cells (30), inhibited BrdU incorporation with an $\mathrm{IC}_{50}$ value of $41 \pm 2 \mu \mathrm{M}\left(n_{\text {Hill }}=4\right.$, Fig. 13C). Tamoxifen, which blocks VRAC in ELA cells potently 


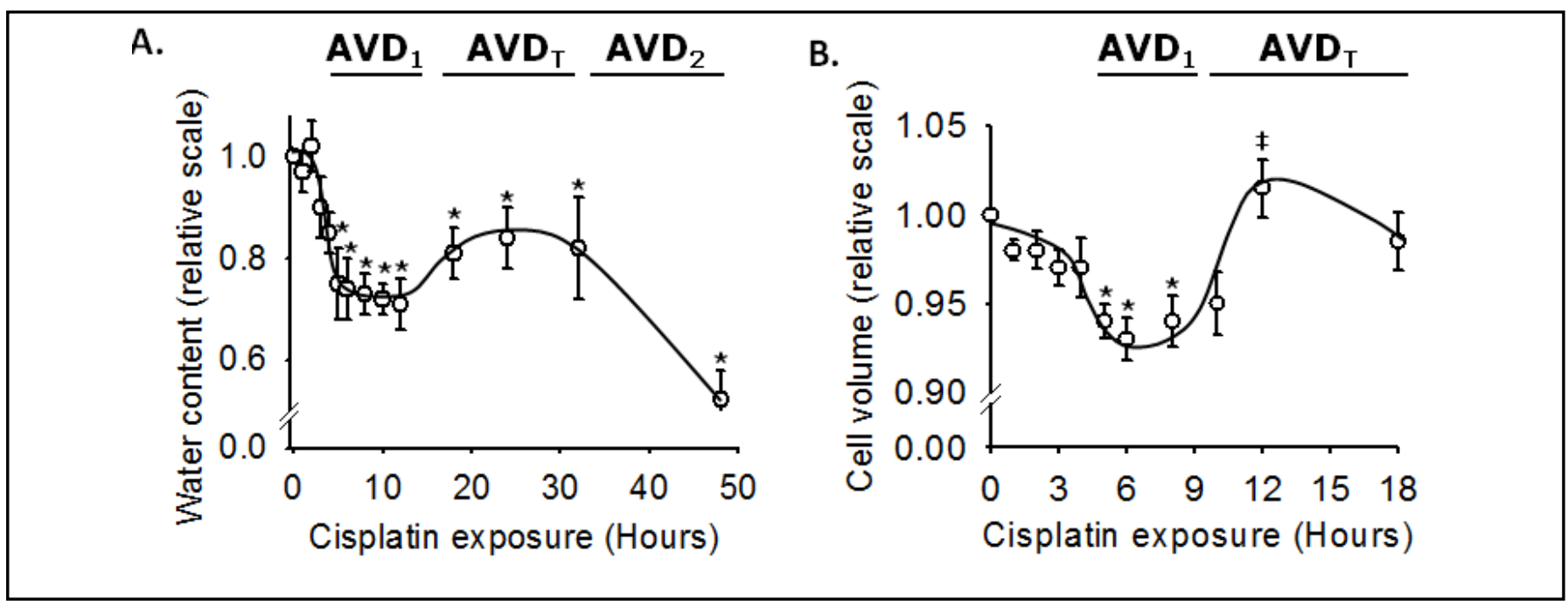

Fig. 15. Typical Apoptotic volume decrease (AVD) after addition of a chemotherapeutic drug. Wild type EATC were incubated with $5 \mu \mathrm{M}$ cisplatin, and samples were taken at different times for estimations of cell water content. (A) Cisplatin-induced apoptosis was divided into three distinguishable stages $\left(\mathrm{AVD}_{1}, \mathrm{AVD}_{\mathrm{T}}\right.$ (transition), and $\left.\mathrm{AVD}_{2}\right)$ based on time-dependent changes in the cell water and volume. Cell water measurements are presented as $\mathrm{ml} / \mathrm{g}$ dry weight, normalized to values obtained at time $=$ 0 , and expressed as the mean values \pm SEM of 8 independent experiments. *indicates significantly different from the initial value obtained at time $=0$, based on ANOVA with the Tukey-Kramer multiple comparison test. (B) Cell volume (in $\mathrm{fL}$ ) was measured by electronic cell sizing (Coulter Counter) under the same conditions as those shown in (A). Values are given relative to the initial cell volume and represents mean values \pm SEM of 11 experiments. *indicates significantly different from the initial value obtained at time $=0 ;{ }^{*}$ indicates significantly different from $\mathrm{AVD}_{1}$. Data were tested for significance with a repeated measures ANOVA and the Tukey-Kramer multiple comparison test. This figure is reproduced from [49] with permission from the American Physiological Society.

inhibited proliferation with an $\mathrm{IC}_{50}$ value of $5.8 \pm 0.8 \mu \mathrm{M}$ $\left(n_{\text {Hill }}=1.3\right.$, Fig. $\left.13 \mathrm{D}\right)$. Notably, both compounds inhibited progression of the cell cycle almost $100 \%$ [31]. The broad spectrum $\mathrm{Cl}^{-}$channel inhibitor DIDS did not affect proliferation (Fig. 13A) and the ELA cell CaCC inhibitor niflumic acid only had minor effects at very high concentrations (Fig. 13B). We further evaluated the role of $\mathrm{Cl}^{-}$ channels in ELA cell cycle progression by measuring three types of $\mathrm{Cl}^{-}$currents in the $\mathrm{G} 0, \mathrm{G} 1$, and S phases. (i) Swelling -activated $\mathrm{Cl}^{-}$currents were measured after osmotic swelling (i.e., VRAC); (ii) $\mathrm{Ca}^{2+}$-activated $\mathrm{Cl}^{-}$ currents were measured after an increase in the free intracellular $\mathrm{Ca}^{2+}$ concentration (i.e., the $\mathrm{CaCC}$ ); and (iii) $\mathrm{Cl}^{-}$currents were measured under isotonic steady-state conditions. The maximal VRAC current decreased from G0 to G1 and increased in early S phase [29] (Fig. 14). The isotonic steady-state current (predominantly VRAC), also decreased in $\mathrm{G} 1$ and increased in early $\mathrm{S}$ phase. In contrast, the maximal CaCC current $\left(500 \mathrm{nM} \mathrm{Ca}^{2+}\right.$ in the patch pipette) was unchanged from G0 to G1 and decreased in early $\mathrm{S}$ phase. Also, other studies showed that CLIC1 and ClC-2 were down regulated in the S phase in ELA cells, in contrast to VRAC [31]. It was suggested

Ion Channels in Regulatory Volume Decrease in Ehrlich Cells

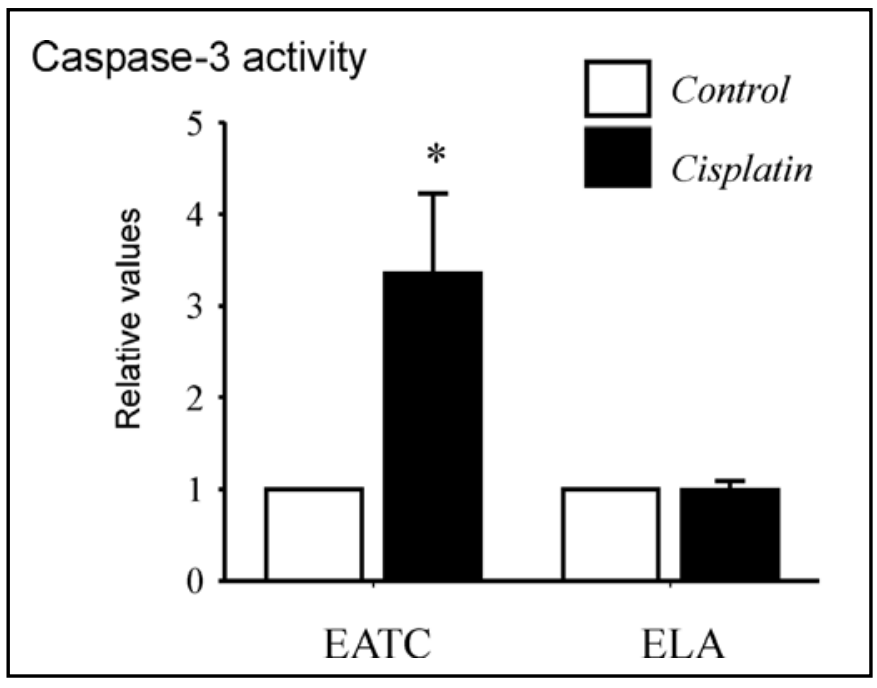

Fig. 16. Caspase-3 activity in non-adherent EATC and adherent ELA cells following cisplatin exposure. EATC and ELA cells were exposed to $10 \mu \mathrm{M}$ cisplatin for $18 \mathrm{~h}$. Caspase-3 activity was estimated with a colorimetric assay. Values for cisplatin treated cells (black bars) are expressed relative to untreated control cells (open bars). The values are means \pm SEM of 7 (EATC) and 3 (ELA) independent experiments. ** indicates significantly increased compared to untreated control $(\mathrm{p}<0.01)$. [Data from [106]]. 
that, in ELA cells, entrance into the $\mathrm{S}$ phase requires an increase in VRAC activity and/or an increased potential for RVD, and a concurrent membrane hyperpolarization, and alteration in $\mathrm{Ca}^{2+}$ signalling through down regulation of $\mathrm{CaCC}$, CLIC1, and $\mathrm{ClC}-2$ [29].

\section{Programmed cell death}

An important aspect of apoptosis is a change in the ion gradient across the plasma membrane, followed by cell shrinkage; this is called an "apoptotic volume decrease" (AVD) [83]. The shrinkage seems to be required for apoptosis, and it starts early after the apoptotic stimuli [49, 83-85]. Okada and co-workers [86]) were the first to show that cell shrinkage during AVD triggered the apoptotic process; Bortner and Cidlowsky proposed the concept of an early AVD followed by a late AVD [87]. We have investigated the AVD process and ion content changes in wild-type (WT) and multidrug-resistant (MDR) EATC [49]. Exposure of WT EATC to $5 \mu \mathrm{M}$ cisplatin resulted in dynamic changes in cell water content and cell volume. As shown in Figure 15, these changes fell into three sub-stages: an early $\operatorname{AVD}(1)$ stage, coupled with a $30 \%$ loss of cell water; a recovery transition stage AVD(T), and a late AVD(2) stage, where cell volume (water) was further reduced. $\operatorname{AVD}(1)$ and $\operatorname{AVD}(2)$ were coupled to a cellular loss of $\mathrm{Cl}^{-}, \mathrm{K}^{+}, \mathrm{Na}^{+}$, and amino acids (ninhydrin-positive substances); the recovery phase was coupled to an uptake of $\mathrm{Na}^{+}, \mathrm{K}^{+}$, and $\mathrm{Cl}^{-}$[49]. The loss of cations exceeded the loss of anions during AVD(1) in EATC [49], as was previously demonstrated during the RVD process [88]. This resulted from $\mathrm{Cl}^{-}$exchanged for $\mathrm{HCO}_{3}^{-}$via the anion exchanger. This caused cytoplasmic acidification, which is a general phenomenon during AVD [78]. Inclusion of the anion channel inhibitor NS3728 in the incubation media caused a dose-dependent inhibition of cisplatin-stimulated caspase 3 activity in WT EATC. At $17 \mu \mathrm{M}$ free NS3728, no caspase 3 activation remained. Thus, early-phase, channel-mediated loss of $\mathrm{K}^{+}, \mathrm{Cl}^{-}$, and cell water was essential for capase activation [49]. Reductions in the concentrations of intracellular ions, specifically $\mathrm{K}^{+}$, was previously suggested to promote caspase activation [89]. In WT EATC, caspase 3 activity was induced during $\operatorname{AVD}(1)$ (4-12 h after cisplatin), when the $\mathrm{K}^{+}$concentration was reduced by only $23 \mathrm{mM}$ [49]; therefore, it was unlikely that a decrease in $\mathrm{K}^{+}$was the differentiating factor. However, caspase activity was further augmented during $\operatorname{AVD}(2)$ concomitant to a major decrease in $\mathrm{K}^{+}$concentration.
Thus, it remains likely that a decrease in $\mathrm{K}^{+}$concentration plays a role in caspase activation.

MDR EATC were resistant to the chemotherapeutic drug cisplatin. Upon addition of cisplatin, these cells showed significantly decreased caspase 3 activation. This was correlated with a less pronounced $\operatorname{AVD}(1)$, an augmented $\operatorname{AVD}(T)$, and a delayed and inhibited $\operatorname{AVD}(2)$ compared to WT EATC. These changes in AVD in MDR EATC could be explained by an inhibition of $\mathrm{Cl}^{-}$efflux during AVD(1) and AVD(2) and an increase in $\mathrm{NaCl}$ uptake during $\mathrm{AVD}(\mathrm{T})$. The differences in $\mathrm{AVD}$, ionic movements, and caspase 3 activation between WT and MDR EATC were abolished in the presence of the anion channel inhibitor NS3728. This suggested that part of the multidrug resistance mechanism was the inhibition of AVD, primarily via inhibition of $\mathrm{Cl}^{-}$movement.

To our surprise, we found that ELA cells also showed a resistance to cisplatin treatment, similar to that observed in MDR EATC (Fig. 16). Because the ELA cells were adherent and EATCs were non-adherent, the cell-lines were expected to have different compositions of the extracellular matrix-binding proteins, integrins, which are essential cell adhesion receptors. Integrins have been proposed to be primary volume sensors, but this remains to be confirmed [61]. Moreover, they have been shown to play a role in apoptosis $[90,91]$. Thus, blocking integrin $\beta 1$ or $\alpha 3$ decreased adhesion and increased apoptosis in fetal islet cells [91]. We are presently investigating these integrins in EATC and ELA cells to determine whether the difference in adherence is important for cell volume regulation and apoptosis induction (Broberg et al., unpublished results).

\section{Shrinkage as a signal for apoptosis}

To determine whether cell shrinkage alone can induce apoptosis, potential links between apoptosis and hypertonic cell shrinkage have been studied in several cell types, including ELA cells [92-94]. It was found that hypertonic cell shrinkage did result in apoptosis [7].

Shrinkage-induced cell death has been shown to involve various signalling events, including two that were studied in our group. The first was that, in NIH3T3 cells, as in many other cell types, cell shrinkage activates the small, monomeric, GTP binding protein, Rac, and the MAP kinase, $\mathrm{p} 38$. This is followed by phosphorylation and nuclear translocation of the transcription factor $\mathrm{p} 53$, which results in caspase 3 activation. Caspase 3 was suggested to cause altered transcription of proapoptotic proteins, including Bax and Bid [93] (Fig. 17A). Overexpression of constitutively active Rac potentiated the shrinkage- 


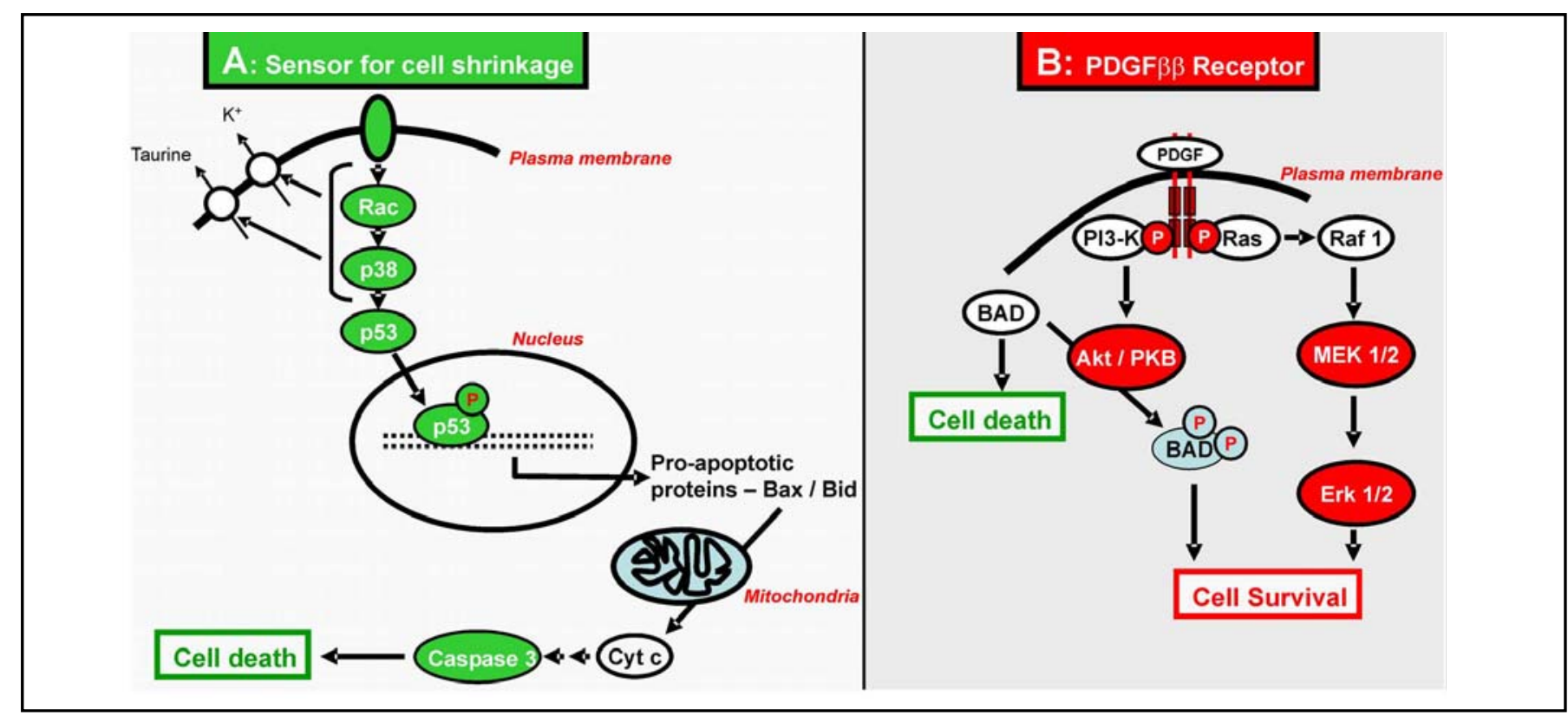

Fig. 17. Two proposed mechanisms for cell shrinkage causing apoptosis. (A) Cell shrinkage activates the monomeric GTP binding protein, Rac, and the MAP kinase, p38, followed by phosphorylation and nuclear translocation of the transcription factor, p53. This results in caspase-3 activation, probably via transcription of proapoptotic proteins. Green indicates stimulatory pathways supported by experimental evidence. The model is based on [93]. (B) Cell shrinkage inhibits PDGF ${ }_{\beta \beta}$ receptor-mediated signalling. Red indicates inhibited pathways that are supported by experimental evidence. Inhibition of PDGF ${ }_{\beta \beta}$ receptor signalling reduces Akt/PKB activity, which results in reduced BAD phosphorylation; this increases BAD-mediated programmed cell death. In addition, reductions in MEK1/2 and ERK 1/2 activities are known to result in reduced cell survival. Based on results from [96]. Models are slightly modified from [7]; reproduced with permission from The American Physiological Society.

induced activation of p38 MAPK, p53, and caspase-3; this suggested that Rac was upstream of these events [93]. The second signalling event was that cell shrinkage inhibits the growth-factor receptor, $\mathrm{PDGF}_{\beta \beta}$; this results in reduced Akt, MEK, and ERK activities [95, 96] (Fig. 17B). Thus, the phosphorylation of ERK $1 / 2$ was transiently decreased in NIH3T3 cells $[93,96]$ and ELA cells [94] after osmotic shrinkage in parallel with the activation of $\mathrm{p} 38$ MAPK.

\section{Cell motility}

Many cell volume regulatory channels and transport proteins play essential roles in cell motility [97, 98], [7, 99]. The Schwab group [99] suggested a model where shrinkage-activated transporters were expressed at the leading edge of the cell; there, they mediated local ion uptake and cell swelling, which contributed to leading edge protrusion. $\mathrm{Cl}^{-}$and $\mathrm{K}^{+}$channels at the lagging edge then mediated ion efflux and cell shrinkage, which contributed to lagging edge retraction. Thus, swelling -activated $\mathrm{Cl}^{-}$ channels modulated cell migration [100] and invasion [101,

Ion Channels in Regulatory Volume Decrease in Ehrlich Cells
102]. Moreover, in H-Ras transformed fibroblasts, swelling -activated $\mathrm{Cl}^{-}$channel upregulation accounted for the increased migratory capacity of these cells [103]. Finally, I shall only briefly outline preliminary findings in ELA cells, which showed that various TMEM16 channels played a role in cell migration. Stable knock downs of TMEM16F and TMEM16K channels were constructed in ELA cell lines. Then, wound healing assays were performed to measure the rate of cell migration. We found that the migration process had slowed down in both knocked down cell lines; this indicated that these $\mathrm{Cl}^{-}$channels played an important role in migration (Jacobsen et al., unpublished results).

\section{Concluding remarks}

Some of the most essential questions for future studies in EATC and ELA cells are the molecular identity of VRAC and the precise molecular mechanisms that underlie the swell-induced activation of channels involved in RVD. These investigations will require studies of ion transport dynamics and structure-function analyses of 
membrane proteins. In addition, we lack knowledge on the contribution of cell volume regulatory mechanisms to the mechanisms involved in cell migration, proliferation, and apoptosis. Further experimental effort is needed to define fully the role of cell volume regulatory mechanisms in these processes.

\section{Acknowledgements}

I gratefully acknowledge funding from the Danish Research Council (FNU and FSS), the Carlsberg Foundation, the Lundbeck foundation, and the Novo Nordisk Foundation.

\section{References}

1 KROGH A: Croonian lecture: The active and passive exchanges of inorganic ions through the surfaces of living cells and through living membranes generally. Proc R Soc Med 1946;133:140-200.

-2 LEAF A: Maintenance of concentration gradients and regulation of cell volume. 13 Ann N Y Acad Sci 1959;72:396-404.

3 USSING HH: Active and passive transport of the alkali metal ions; in USSING HH, Kruhöffeer P, Hess Thaysen J, Thorn NA (eds): The alkali metal ions in biology. 1960, pp 45-143.

$\checkmark 4$ Tosteson DC, Hoffman JF: Regulation of cell volume by active cation transport in high and low potassium sheep red cells. J Gen Physiol 1960;44:169-194.

$\checkmark 5$ Lang F, Busch GL, Ritter M, Volkl H, Waldegger S, Gulbins E, Haussinger D: Functional significance of cell volume regulatory mechanisms. Physiol Rev 1998;78:247-306.

-6 Wehner F, Olsen H, Tinel H, KinneSaffran E, Kinne RKH: Cell volume regulation: osmolytes, osmolyte transport, and signal transduction. Rev Physiol Biochem Pharmacol 2003;148:1-80.

7 Hoffmann EK, Lambert IH, Pedersen SF: Physiology of cell volume regulation in vertebrates. Physiol Rev 2009;89:193277

8 Hoffmann EK: Regulation of cell volume by selective changes in the leak permeabilities of Ehrlich ascites tumor cells. Alfred Benzon Symposium 1978;XI:397-417.

$>9$ Lambert IH, Hoffmann EK, Jorgensen F: Membrane potential, anion and cation conductances in Ehrlich ascites tumor cells. J Membr Biol 1989;111:113-131. Hoffmann EK: Intracellular signalling involved in volume regulatory decrease. Cell Physiol Biochem 2000;10:273-288.

11 Krarup T, Jakobsen LD, Jensen BS, Hoffmann EK: $\mathrm{Na}^{+}-\mathrm{K}^{+}-2 \mathrm{Cl}^{-}$cotransport in Ehrlich cells: regulation by protein phosphatases and kinases. Am J Physiol 1998;275:C239-C250.
12 Kirkegaard SS, Lambert IH, Gammeltoft 23 S, Hoffmann EK: Activation of the TASK-2 channel after cell swelling is dependent on tyrosine phosphorylation Am J Physiol Cell Physiol 2010;299:C844-C853.

3 Grinstein S, Clarke CA, Rothstein A: Increased anion permeability during volume regulation in human lymphocytes. Philos Trans R Soc Lond B Biol Sci 1982;299:509-518.

14 Nilius B, Eggermont J, Voets T, Buyse G, Manolopoulos V, Droogmans G: Properties of volume-regulated anion channels in mammalian cells. Prog Biophys Mol 26 Biol 1997;68:69-119.

15 Okada Y: Volume expansion-sensing outward-rectifier $\mathrm{Cl}^{-}$channel: fresh start to the molecular identity and volume sensor. Am J Physiol 1997;273:C755-C789. Hazama A, Okada Y: $\mathrm{Ca}^{2+}$ sensitivity of volume-regulatory $\mathrm{K}^{+}$and $\mathrm{Cl}^{-}$channels in cultured human epithelial cells. J Physiol 1988;402:687-702.

17 Gunn RB, Dalmark M, Tosteson DC, 28 Wieth JO: Characteristics of chloride transport in human red blood cells. J Gen Physiol 1973;61:185-206.

18 Hoffmann EK, Simonsen LO, Sjoholm C: Membrane potential, chloride exchange, and chloride conductance in Ehrlich mouse ascites tumour cells. J Physiol 1979;296:61-84.

-19 Hendil KB, Hoffmann EK: Cell volume regulation in Ehrlich ascites tumor cells. J Cell Physiol 1974;84:115-125.

20 Hoffmann EK, Lambert IH, Simonsen LO: Separate, $\mathrm{Ca}^{2+}$-activated $\mathrm{K}^{+}$and $\mathrm{Cl}^{-}$ transport pathways in Ehrlich ascites tumor cells. J Membr Biol 1986;91:227244.

-21 Hoffmann EK: The pump and leak steady-state concept with a variety of regulated leak pathways. J Membr Biol 2001;184:321-330.

-22 Duran C, Thompson CH, Xiao Q, Hartzell HC: Chloride channels: often enigmatic, rarely predictable. Annu Rev Physiol 2010;72:95-121.
Pedersen SF, Prenen J, Droogmans G, Hoffmann EK, Nilius B: Separate swelling- and $\mathrm{Ca}^{2+}$-activated anion currents in Ehrlich ascites tumor cells. J Membr Biol 1998;163:97-110.

Klausen TK, Hougaard C, Hoffmann EK, Pedersen SF: Cholesterol modulates the volume-regulated anion current in Ehrlich-Lettre ascites cells via effects on Rho and F-actin. Am J Physiol Cell Physiol 2006;291:C757-C771.

Nilius B, Droogmans G: Amazing chloride channels: an overview. Acta Physiol Scand 2003;177:119-147.

Jackson PS, Strange K: Characterization of the voltage-dependent properties of a volume-sensitive anion conductance. J Gen Physiol 1995;105:661-676.

$\checkmark 27$ Lepple-Wienhues A, Szabo I, Laun T, Kaba NK, Gulbins E, Lang F: The tyrosine kinase p56lck mediates activation of swelling-induced chloride channels in lymphocytes. J Cell Biol 1998;141:281286.

Vanoye CG, Altenberg GA, Reuss L: Pglycoprotein is not a swelling-activated $\mathrm{Cl}^{-}$channel; possible role as a $\mathrm{Cl}^{-}$channel regulator. J Physiol 1997;502:249-258.

Klausen TK, Bergdahl A, Hougaard C, Christophersen P, Pedersen SF, Hoffmann EK: Cell cycle-dependent activity of the volume- and $\mathrm{Ca}^{2+}$-activated anion currents in Ehrlich lettre ascites cells. J Cell Physiol 2007;210:831-842.

Christensen O, Hoffmann EK: Cell swelling activates $\mathrm{K}^{+}$and $\mathrm{Cl}^{-}$channels as well as nonselective, stretch-activated cation channels in Ehrlich ascites tumor cells. J Membr Biol 1992;129:13-36.

Klausen TK, Preisler S, Pedersen SF, Hoffmann EK: Monovalent ions control proliferation of Ehrlich Lettre ascites cells. Am J Physiol Cell Physiol 2010;299:C714-C725.

32 Duran C, Hartzell HC: Physiological roles and diseases of Tmem16/Anoctamin proteins: are they all chloride channels? Acta Pharmacol Sin 2011;32:685-692. Hoffmann EK, Pedersen SF: Sensors and signal transduction in the activation of cell volume regulatory ion transport systems. Contrib Nephrol 1998;123:50-78. 
-34 Jorgensen NK, Christensen S, Harbak H, Brown AM, Lambert IH, Hoffmann EK, Simonsen LO: On the role of calcium in the regulatory volume decrease (RVD) response in Ehrlich mouse ascites tumor cells. J Membr Biol 1997;157:281-299.

\3 Lambert IH, Klausen TK, Bergdahl A, Hougaard C, Hoffmann EK: ROS activate $\mathrm{KCl}$ cotransport in nonadherent Ehrlich ascites cells but $\mathrm{K}^{+}$and $\mathrm{Cl}^{-}$channels in adherent Ehrlich Lettre and NIH3T3 cells. Am J Physiol Cell Physiol 2009;297:C198-C206.

$\checkmark 36$ Klausen TK, Hougaard C, Hoffmann EK, Pedersen SF: Cholesterol modulates the volume-regulated anion current in Ehrlich-Lettre ascites cells via effects on Rho and F-actin. Am J Physiol Cell Physiol 2006;291:C757-C771.

\37 Levitan I, Christian AE, Tulenko TN, Rothblat GH: Membrane cholesterol content modulates activation of volumeregulated anion current in bovine endothelial cells. J Gen Physiol 2000;115:405-416.

>3 Lauritzen L, Hoffmann EK, Hansen HS, Jensen B: Dietary n-3 and n-6 fatty acids are equipotent in stimulating volume regulation in Ehrlich ascites tumor cells. Am J Physiol 1993;264:C109-C117.

$\checkmark 39$ Hoffmann EK, Pedersen SF: Shrinkage insensitivity of NKCC1 in myosin IIdepleted cytoplasts from Ehrlich ascites tumor cells. Am J Physiol Cell Physiol 2007;292:C1854-C1866.

$\checkmark 40$ Varela D, Simon F, Riveros A, Jorgensen F, Stutzin A: NAD $(\mathrm{P}) \mathrm{H}$ oxidase-derived $\mathrm{H}(2) \mathrm{O}(2)$ signals chloride channel activation in cell volume regulation and cell proliferation. J Biol Chem 2004;279:13301-13304.

$\checkmark 41$ Shimizu T, Numata T, Okada Y: A role of reactive oxygen species in apoptotic activation of volume-sensitive $\mathrm{Cl}^{-}$channel. Proc Natl Acad Sci USA 2004;101:6770-6773.

-42 Browe DM, Baumgarten CM: Angiotensin II (AT1) receptors and NADPH oxidase regulate $\mathrm{Cl}^{-}$current elicited by betal integrin stretch in rabbit ventricular myocytes. J Gen Physiol 2004;124:273287.

-43 Roti Roti LW, Rothstein A: Adaptation of mouse leukemic cells (L5178Y) to anisotonic media. I. Cell volume regulation. Exp Cell Res 1973;79:295-310.

$\checkmark 44$ Niemeyer MI, Cid LP, Barros LF, Sepulveda FV: Modulation of the twopore domain acid-sensitive $\mathrm{K}^{+}$channel TASK-2 (KCNK5) by changes in cell volume. J Biol Chem 2001;276:4316643174.

$\checkmark 45$ Niemeyer MI, Hougaard C, Hoffmann EK, Jorgensen F, Stutzin A, Sepulveda FV: Characterisation of a cell swellingactivated $\mathrm{K}^{+}$-selective conductance of ehrlich mouse ascites tumour cells. J Physiol 2000;524:757-767.
Riquelme G, Sepulveda FV, Jorgensen F, Pedersen S, Hoffmann EK: Swelling-activated potassium currents of Ehrlich ascites tumour cells. Biochim Biophys Acta 1998;1371:101-106.

\section{7}

Niemeyer MI, Cid LP, Sepulveda FV: $\mathrm{K}^{+}$ conductance activated during regulatory volume decrease. The channels in Ehrlich cells and their possible molecular counterpart. Comp Biochem Physiol A Mol Integr Physiol 2001;130:565-575. Hougaard C, Jorgensen F, Hoffmann EK: Modulation of the volume-sensitive $\mathrm{K}^{+}$ current in Ehrlich ascites tumour cells by pH. Pflugers Arch 2001;442:622-633.

Poulsen KA, Andersen EC, Hansen CF, Klausen TK, Hougaard C, Lambert IH, Hoffmann EK: Deregulation of apoptotic volume decrease and ionic movements in multidrug-resistant tumor cells: role of chloride channels. Am J Physiol Cell Physiol 2010;298:C14-C25.

50 Bittner S, Bobak N, Herrmann AM, Gobel K, Meuth P, Hohn KG, Stenner MP, Budde T, Wiendl H, Meuth SG: Upregulation of K2P5.1 potassium channels in multiple sclerosis. Ann Neurol 2010;68:58-69.

Jorgensen NK, Lambert IH, Hoffmann EK: Role of LTD4 in the regulatory volume decrease response in Ehrlich ascites tumor cells. J Membr Biol 1996;151:159173.

Hoffmann EK: Leukotriene D4 (LTD4) activates charybdotoxin-sensitive and insensitive $\mathrm{K}^{+}$channels in ehrlich ascites tumor cells. Pflugers Arch 1999;438:263268 .

53 Hougaard C, Niemeyer MI, Hoffmann EK, Sepulveda FV: $\mathrm{K}^{+}$currents activated by leukotriene D4 or osmotic swelling in Ehrlich ascites tumour cells. Pflugers Arch 2000;440:283-294.

Kirkegaard SS, Lambert IH, Gammeltoft 67 S, Hoffmann EK: Activation of the TASK-2 channel after cell swelling is dependent on tyrosine phosphorylation. Am J Physiol Cell Physiol 2010;299:C844-C853.

Niemeyer MI, Stutzin A, Sepulveda FV: A $>68$ voltage-independent $\mathrm{K}^{+}$conductance activated by cell swelling in Ehrlich cells is modulated by a G-protein-mediated process. Biochim Biophys Acta 2002;1562:15.

Pedersen S, Lambert IH, Thoroed SM, Hoffmann EK: Hypotonic cell swelling induces translocation of the alpha isoform of cytosolic phospholipase A2 but not the gamma isoform in Ehrlich ascites tumor cells. Eur J Biochem 2000;267:5531-5539.

Lambert IH, Hoffmann EK, Christensen P: Role of prostaglandins and leukotrienes in volume regulation by Ehrlich ascites tumor cells. J Membr Biol 1987;98:247-256.
Mollerup J, Jorgensen ST, Hougaard C, Hoffmann EK: Identification of a murine cysteinyl leukotriene receptor by expression in Xenopus laevis oocytes. Biochim Biophys Acta 2001;1517:455-459.

Dezaki K, Tsumura T, Maeno E, Okada Y: Receptor-mediated facilitation of cell volume regulation by swelling-induced ATP release in human epithelial cells. Jpn J Physiol 2000;50:235-241.

60 Pedersen SF, Pedersen S, Lambert IH, Hoffmann EK: P2 receptor-mediated signal transduction in Ehrlich ascites tumor cells. Biochim Biophys Acta 1998;1374:94-106.

61 Pedersen SF, Kapus A, Hoffmann EK: Osmosensory mechanisms in cellular and systemic volume regulation. Am Soc Nephrol 2011;22:1587-1597.

62 Minton AP, Colclasure GC, Parker JC: Model for the role of macromolecular crowding in regulation of cellular volume. Proc Natl Acad Sci USA 1992;89:10504-10506.

63 Burg MB: Macromolecular crowding as a cell volume sensor. Cell Physiol Biochem 2000;10:251-256.

64 Nilius B, Prenen J, Voets T, Eggermont J, Droogmans G: Activation of volumeregulated chloride currents by reduction of intracellular ionic strength in bovine endothelial cells. J Physiol-London 1998;506:353-361.

Dunham PB, Kelley SJ, Logue PJ: Extracellular $\mathrm{Na}^{+}$inhibits $\mathrm{Na}^{+} / \mathrm{H}^{+}$exchange: cell shrinkage reduces the inhibition. Am J Physiol Cell Physiol 2004;287:C336C344.

66 Pedersen SF, Mills JW, Hoffmann EK: Role of the F-actin cytoskeleton in the RVD and RVI processes in Ehrlich ascites tumor cells. Exp Cell Res 1999;252:6374.

Pedersen SF, Hoffmann EK: Possible interrelationship between changes in F-actin and myosin II, protein phosphorylation, and cell volume regulation in Ehrlich ascites tumor cells. Exp Cell Res 2002;277:57-73.

Pedersen SF, Beisner KH, Hougaard C, Willumsen BM, Lambert IH, Hoffmann EK: Rho family GTP binding proteins are involved in the regulatory volume decrease process in NIH3T3 mouse fibroblasts. J Physiol 2002;541:779-796. Rasmussen M, Alexander RT, Darborg BV, Mobjerg N, Hoffmann EK, Kapus A, Pedersen SF: Osmotic cell shrinkage activates ezrin/radixin/moesin (ERM) proteins: activation mechanisms and physiological implications. Am J Physiol Cell Physiol 2008;294:C197-C212.

Olsen H, ter Veld F, Herbrand U, Ahmadian MR, Kinne RK, Wehner F: Differential regulation of cell volume and shape in confluent rat hepatocytes under hypertonic stress. Cell Physiol Biochem 2007;19:259-268. 
77 Ciano-Oliveira C, Sirokmany G, Szaszi K, Arthur WT, Masszi A, Peterson M, Rotstein OD, Kapus A: Hyperosmotic stress activates Rho: differential involvement in Rho kinase-dependent MLC phosphorylation and NKCC activation. Am J Physiol Cell Physiol 84
2003;285:C555-C566.

72 Mills JW, Falsig PS, Walmod PS, Hoffmann EK: Effect of cytochalasins on F-actin and morphology of Ehrlich ascites tumor cells. Exp Cell Res 2000;261:209-219.

73 Pedersen SF, Hoffmann EK, Mills JW: The cytoskeleton and cell volume regulation. Comp Biochem Physiol A Mol Integr Physiol 2001;130:385-399.

74 Jorgensen NK, Pedersen SF, Rasmussen HB, Grunnet M, Klaerke DA, Olesen SP: Cell swelling activates cloned $\mathrm{Ca}^{2+}$-activated $\mathrm{K}^{+}$channels: a role for the $\mathrm{F}$-actin cytoskeleton. Biochim Biophys Acta 2003;1615:115-125.

75 Jessen F, Hoffmann EK: Activation of the $\mathrm{Na}^{+} / \mathrm{K}^{+} / \mathrm{Cl}^{-}$cotransport system by reorganization of the actin filaments in Ehrlich ascites tumor cells. Biochim Biophys Acta 1992;1110:199-201.

76 Matthews JB, Smith JA, Mun EC, Sicklick JK: Osmotic regulation of intestinal epithelial $\mathrm{Na}^{+}-\mathrm{K}^{+}-\mathrm{Cl}^{-}$cotransport: role of $\mathrm{Cl}^{-}$ and F-actin. Am J Physiol 1998;274:C697-C706.

$>77$ Lang F, Shumilina E, Ritter M, Gulbins E, Vereninov A, Huber SM: Ion channels and cell volume in regulation of cell proliferation and apoptotic cell death. Contrib Nephrol 2006;152:142-160.

78 Lang F, Foller M, Lang K, Lang P, Ritter M, Vereninov A, Szabo I, Huber SM, Gulbins E: Cell volume regulatory ion channels in cell proliferation and cell death. Methods Enzymol 2007;428:209. 225

79 Prevarskaya N, Skryma R, Shuba Y: Ion channels and the hallmarks of cancer. $\$ 92$ Trends Mol Med 2010;16:107-121.

$>0$ Klausen TK, Preisler S, Pedersen SF, Hoffmann EK: Monovalent ions control proliferation of Ehrlich Lettre ascites cells. Am J Physiol Cell Physiol 2010;299:C714-C725.

$>81$ Chen LX, Zhu LY, Jacob TJ, Wang LW: Roles of volume-activated $\mathrm{Cl}^{-}$currents and regulatory volume decrease in the cell cycle and proliferation in nasopharyngeal carcinoma cells. Cell Prolif 2007;40:253-267.

-82 Shen MR, Droogmans G, Eggermont J, Voets T, Ellory JC, Nilius B: Differential expression of volume-regulated anion channels during cell cycle progression of human cervical cancer cells. J Physiol 2000;529:385-394.
Maeno E, Ishizaki Y, Kanaseki T, Hazama A, Okada Y: Normotonic cell shrinkage because of disordered volume regulation is an early prerequisite to apoptosis. Proc Natl Acad Sci USA 2000;97:9487-9492.

Bortner CD, Hughes FM Jr, Cidlowski JA: A primary role for $\mathrm{K}^{+}$and $\mathrm{Na}^{+}$efflux in the activation of apoptosis. J Biol Chem 1997;272:32436-32442.

-85 Okada Y, Maeno E, Shimizu T, Dezaki $\mathrm{K}$, Wang J, Morishima S: Receptor-mediated control of regulatory volume decrease (RVD) and apoptotic volume decrease (AVD). J Physiol 2001;532:3-16. Okada Y, Maeno E: Apoptosis, cell volume regulation and volume-regulatory chloride channels. Comp Biochem Physiol A Mol Integr Physiol 2001;130:377-383.

$>87$ Bortner CD, Sifre MI, Cidlowski JA: Cationic gradient reversal and cytoskeletonindependent volume regulatory pathways define an early stage of apoptosis. J Biol Chem 2008;283:7219-7229.

$\checkmark 88$ Livne A, Hoffmann EK: Cytoplasmic acidification and activation of $\mathrm{Na}^{+} / \mathrm{H}^{+}$ exchange during regulatory volume decrease in Ehrlich ascites tumor cells. J Membr Biol 1990;114:153-157.

89 Bortner CD, Cidlowski JA: Cell shrinkage and monovalent cation fluxes: role in apoptosis. Arch Biochem Biophys 2007;462:176-188.

$\$ 90$ Gilmore AP, Owens TW, Foster FM, Lindsay J: How adhesion signals reach a mitochondrial conclusion-ECM regulation of apoptosis. Curr Opin Cell Biol 2009;21:654-661.

Krishnamurthy M, Li J, Fellows GF, Rosenberg L, Goodyer CG, Wang R: Integrin $\{$ alpha $\} 3$, but not $\{$ beta $\} 1$, regulates islet cell survival and function via PI3K/Akt signaling pathways. Endocrinology 2011;152:424-435.

Nylandsted J, Jaattela M, Hoffmann EK, Pedersen SF: Heat shock protein 70 inhibits shrinkage-induced programmed cell death via mechanisms independent of effects on cell volume-regulatory membrane transport proteins. Pflugers Arch 2004;449:175-185.

\$93 Friis MB, Friborg CR, Schneider L, Nielsen MB, Lambert IH, Christensen ST, Hoffmann EK: Cell shrinkage as a signal to apoptosis in NIH 3 T3 fibroblasts. J Physiol 2005;567:427-443.

94 Pedersen SF, Darborg BV, Rasmussen M, Nylandsted J, Hoffmann EK: The $\mathrm{Na}^{+} /$ $\mathrm{H}^{+}$exchanger, NHE1, differentially regulates mitogen-activated protein kinase subfamilies after osmotic shrinkage in Ehrlich Lettre Ascites cells. Cell Physiol Biochem 2007;20:735-750.
Copp J, Wiley S, Ward MW, van der Geer P: Hypertonic shock inhibits growth factor receptor signaling, induces caspase-3 activation, and causes reversible fragmentation of the mitochondrial network. Am J Physiol Cell Physiol 2005;288:C403C415.

$\$ 96$ Nielsen MB, Christensen ST, Hoffmann EK: Effects of osmotic stress on the activity of MAP kinases and PDGFR \{beta $\}$-mediated signal transduction in NIH3T3-fibroblasts. Am J Physiol Cell Physiol 2008;294:C1046-1055.

$\$ 97$ Jakab M, Ritter M: Cell volume regulatory ion transport in the regulation of cell migration. Contrib Nephrol 2006;152:161-180.

$\$ 98$ McFerrin MB, Sontheimer H: A role for ion channels in glioma cell invasion. Neuron Glia Biol 2006;2:39-49.

Schwab A, Nechyporuk-Zloy V, Fabian A, Stock C: Cells move when ions and water flow. Pflugers Arch 2007;453:421432.

100 Mao J, Wang L, Fan A, Wang J, Xu B, Jacob TJ, Chen L: Blockage of volumeactivated chloride channels inhibits migration of nasopharyngeal carcinoma cells. Cell Physiol Biochem 2007; 19:249-258.

101 Soroceanu L, Manning TJ Jr, Sontheimer $\mathrm{H}$ : Modulation of glioma cell migration and invasion using $\mathrm{Cl}^{-}$and $\mathrm{K}^{+}$ion channel blockers. J Neurosci 1999;19:59425954.

102 Ransom CB, O’Neal JT, Sontheimer H: Volume-activated chloride currents contribute to the resting conductance and invasive migration of human glioma cells. J Neurosci 2001;21:7674-7683.

103 Schneider L, Klausen TK, Stock C, Mally S, Christensen ST, Pedersen SF, Hoffmann EK, Schwab A: H-ras transformation sensitizes volumeactivated anion channels and increases migratory activity of NIH3T3 fibroblasts. Pflugers Arch 2008;455:1055-1062.

104 Hoffmann EK, Hougaard C: Intracellular signalling involved in activation of the volume-sensitive $\mathrm{K}^{+}$current in Ehrlich ascites tumour cells. Comp Biochem Physiol A Mol Integr Physiol 2001;130:355-366.

105 Hoffmann EK, Pedersen SF: Cell volume homeostatic mechanisms: effectors and signalling pathways. Acta Physiol (Oxf) 2011;202:465-485.

106 Tastesen HS, Holm JB, Moller J, Poulsen KA, Moller C, Sturup S, Hoffmann EK, Lambert IH: Pinpointing differences in cisplatin-induced apoptosis in adherent and non-adherent cancer cells. Cell Physiol Biochem 2010;26:809-820. 